\title{
Natural Water Conductivity Behavior within the Seismic Pacific Coast of Southern Mexico
}

\author{
Fidel Martínez-García ${ }^{1,2 *}$, Arturo Colín-Cruz², Alberto Pereira-Corona3 ${ }^{3}$, \\ Salvador Adame-Martínez ${ }^{4}$, Jorge J. Ramírez-García ${ }^{2}$ \\ ${ }^{1}$ Center of Proposed Drafts of the South Pacific, Federal Electricity Commission, Cuernavaca, Morelos, Mexico \\ ${ }^{2}$ Faculty of Chemistry, Autonomous University of Mexico State, Toluca de Lerdo, Mexico \\ ${ }^{3}$ Department of Applied Ecology to Natural Resource Management, Autonomous University of Quintana Roo, \\ Chetumal, Quintana Roo, Mexico \\ ${ }^{4}$ Faculty of Urban and Regional Planning, Autonomous University of Mexico State, Toluca de Lerdo, Mexico \\ Email: "fidel.martinez@cfe.gob.mx, fmg1376@yahoo.com.mx
}

Received 16 June 2016; accepted 22 July 2016; published 28 July 2016

Copyright (C) 2016 by authors and OALib.

This work is licensed under the Creative Commons Attribution International License (CC BY).

http://creativecommons.org/licenses/by/4.0/

(c) (i) Open Access

\section{Abstract}

Near faults or unstable areas where an earthquake could happen with capacity to damage buildings or infrastructure, there is often a previous energy that wanders around surroundings, this energy regularly is associated with electromagnetic emissions that generate an electric potential frequently studied as very, ultra-low and extreme frequency emissions (VLF-ULF-ELF_ EM) by remote sensing; under the assumption that this natural potential exists, in aquatic environment within the micro-seismic active area in the coastal border of Guerrero and Oaxaca estates, Mexico, an intensive conductivity monitoring in two artesian well was carried out. The results of intensive conductivity $(\mu \mathrm{S} / \mathrm{cm})$ monitoring done since March to July of 2015, using a low-cost Data logger sensor are presented. The results obtained of the study of 235 seismic events show that $61.64 \%$ of them manifest prior conductivity oscillation versus $38.36 \%$ of early conductivity oscillation, the possible origin of such oscillation and the likely relation with underground water recharge flux, ground light compression, ground tilt, local electromagnetic energy emissions, human interaction, was debated. The data analysis for long periods of conductivity monitoring and seismic events show that when the number of seismic events becomes intense, conductivity decreases and vice versa, resulting large fluctuations that grow over time like waves; within the study area a possible previous fluctuated long-term energy associated with earthquakes produced around could be arising.

\section{Keywords}

Electromagnetic Emissions, Earthquakes, Natural Water Conductivity, Water Recharge,

*Corresponding author.

How to cite this paper: Martínez-García, F., Colín-Cruz, A., Pereira-Corona, A., Adame-Martínez, S. and Ramírez-García, J.J. (2016) Natural Water Conductivity Behavior within the Seismic Pacific Coast of Southern Mexico. Open Access Library Journal, 3: e2836. http://dx.doi.org/10.4236/oalib.1102836 


\title{
Previous Phenomenon of Earthquakes, Cocos Plates, Subduction Zones
}

\author{
Subject Areas: Geochemistry
}

\section{Introduction}

In the surrounding environment near areas with intense seismic activity there is a tight relationship among the electric and electromagnetic energy emanating from the Earth's interior and the earthquakes. Although the lithosphere is considered insulating and do not allow the flux of energy to arise from Earth's deep layers, there are discontinuities or weakness zones that make it possible; in general these areas are located all over the world where oceanic and continental plates collide giving rise to subduction zones [1]-[3]. The kind of energy regularly mentioned corresponds to electromagnetic emission (EME) studied in the range of very, ultra-low and extremely low frequency waves by remote sensing.

When this energy arrives at the Earth' surface [4]-[6], it affects the local ionosphere by changing the local atmospheric electricity [4]-[16], heating and increasing the local relative humidity [9] [12] [17] [18]; all of these anomalies that upset the local environment lead to luminous phenomena [9] [12] [19]-[21] and formation of aerosols and clouds [22]-[28]; some of these phenomena have been associated with changes in animal and human behavior because of presence of a charged atmosphere with positive ions [9] [12] [13] [24] [29]-[36]. It is known that the electromagnetic emission (EME) also enhances natural radiation related to molecular decay of Radon gas that issues from each fracture of rock, particularly enhances its ionizing energy, as occurs near power transmission lines [37]-[40].

Taking in account the main importance of this type of energy that emanates from the ground and flows in the natural environment preceding earthquakes and natural phenomena involved, the purpose of this research is to detect this energy indirectly by determining natural water conductivity under the assumption that this energy wanders around near faults or unstable areas where an earthquake occurs.

\section{Study Area Description}

Mexico is one of the most seismic countries in the world, after Japan, Indonesia, Chile, Papua New Guinea and Turkey, particularly to the south and southeast of the country within the States of Michoacán, Guerrero, Oaxaca and Chiapas, this is due to the process of subduction associated to The Middle America Trench (MAT) in the Pacific coast of southern Mexico. In this place converge the continental North America and the oceanic Cocos plates, considered the most important tectonic features of Mexico [41]. The plate of Cocos moves almost horizontal 300 kilometers below the North American plate at rate of six centimeters per year downwards in the terrestrial mantle with a $55^{\circ}$ inclination angle [42].

Of 2006 to 2015 were registered 32819 seismic events ( $>3 \mathrm{Mw}$ ), of which 18773 have taken place in the Pacific Ocean and 14046 in the continental area, of last grouped near the coast in a fringe of $12 \times 100$ kilometers is concentrated 52\% of them with 7337 events. Within this coastal border in Oaxaca estate limits is located the Pinotepa National municipality, demarcation with a territory of $719.56 \mathrm{~km}^{2}$, in this place is registered the biggest number of seismic events with 1850; this municipality is the most micro-seismic active area per square kilometer with three events [37] [41]; in the interior of this are a occurred on June 30, 2010 an earthquake of M6.0 at 02:22:27 hours and another one by June 25, 2015 of M5.1 at 05:31:46 hours.

The geology of surrounding area represents a transition zone between the coastal lowlands and the southern Sierra Madre (SMS), is complex because of convergence of different cortical blocks bound by faults that include a variety of exposed metamorphic rocks and intrusive bodies. The geomorphology and geology of this area correspond to a coastal plain with Quaternary alluvial materials; it is common to see these accumulations topping the intrusions and gneiss of the Xolapa complex next local rivers courses, hills and piedmonts [41].

The selected area of study correspond to a site called "Corralero" within Pinotepa Nacional municipality in the state of Oaxaca, Mexico, Figure 1, region with the largest number of earthquakes per square kilometer above mentioned [37] [41]. Two places were selected for the intensive conductivity monitoring in aquatic environment, one of them at the geographic coordinates $16^{\circ} 14^{\prime} 10.6^{\prime \prime} \mathrm{N}$ and $98^{\circ} 11.406^{\prime} \mathrm{W}$, and the other one at $16^{\circ} 14^{\prime} 10.5^{\prime \prime} \mathrm{N}$ 


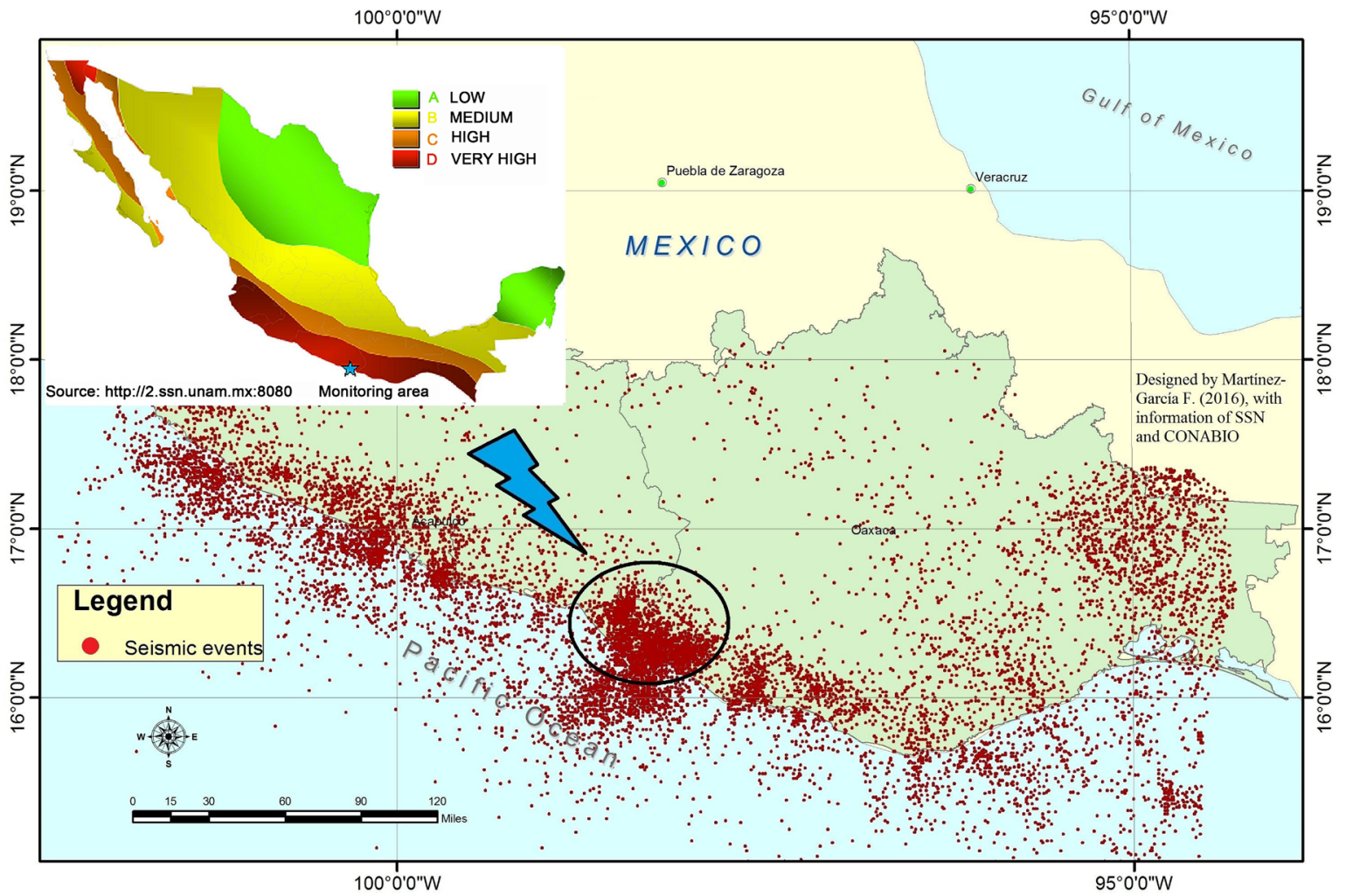

Figure 1. Study area geographic position, this place has the highest number of earthquakes per $\mathrm{km}^{2}$. Obtained from Martínez-García et al., 2015: support information obtained of National Commission for Knowledge and Use of Biodiversity

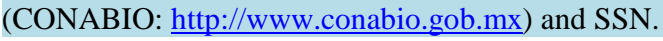

and $98^{\circ} 11^{\prime} 14.5^{\prime \prime}$; they correspond to artesian well of $1 \times 1 \times 6$ meters (CAW01) and $1.3 \times 1.3 \times 3$ meters dimensions (CAW02), respectively.

\section{Scientific Background}

Since past century, the electromagnetic energy(EME) has been studied through of the very, ultra-low and extreme frequency electromagnetic emissions (VLF-ULF-ELF_EM), regularly by remote sensing; considered a previous phenomenon of earthquakes, sometimes is used in short-term prediction of a large earthquake but his study is controversial to date [15] [43] [44]. Apparently there is a subtle correlation between the increase in VLF-ULF-ELF field emissions and the increased seismic activity although other parameters like solar wind could be involved too [5] [45] [46].

This energy is concentrated often near faults or unstable areas where an earthquake could happen and often flow by periods of a few hours or one day during the seismic preparation process, although this period could be longer prior the main event [23] [46], this kind of perturbations prove that is not a casual phenomenon and could be associated with earthquakes [36] [46] [47]. In the earthquake's local neighborhood this phenomenon is associated with thermal anomalies commonly observed by remote sensing [48]-[50].

VLF-ULF-EM field emissions reported show a particular behavior, preceding the earthquake; there is an increase in the number of short pulses until a couple of weeks previous the earthquake [24] [51]. In general, the perturbations observed are responsible for increasing the Earth's surface potential (electric induction) associated with earthquakes; sometimes these anomalies are related with piezoelectric and triboelectric effects; emanation of warm gases from the ground; activation of positive holes; radioactive gas or metallic ions emissions such as Radon gas [10] [12] [52]. The detection of ULF EM signals are in several forms, either asranges of frequency from: 0.01 to $80 \mathrm{kHz}$ and sometimes until to $18 \mathrm{MHz}$, or magnetic signals levels of 0.9 a 5.0 Nano Tesla, nT [9] [14]. 


\section{Materials and Methods}

Electromagnetic signals have extensively used to study the lower ionosphere anomalies previous to earthquakes [1] [5] [45]-[47]. By the inherent importance of this type of energy and his relations with the natural electric induction that produce, if this energy emanates from the ground and flows in the natural environment preceding earthquakes, then this energy could be detectable using a conductivity sensor to ground level. Under the assumption that this energy wanders around to faults or unstable areas where an earthquake could happen, as an indirect way to detect this energy, intensive monitoring were conducted in two artesian wells using a low-cost Data logger HOBO U24-001 sensor to measure the local natural conductivity understood this as a measure of a solution's ability to conduct electricity.

The Data logger HOBO U24-001 [53] uses a non-contact capacitive sensor. This technology consists in an electronic piece called "capacitor" or "condenser" that contain two conductive sensitive electrodes (plates) and materials with low conductivity and high insulation characteristics called dielectric. The water conductivity and the sensor capacitance create a resistor-capacitor circuit (RC circuit) as response to AC stimulation, which varies as a function of the conductivity; essentially this instrument measures the changes of impedance of the circuit as response to water conductance changes.

This investigation in aquatic environment through the intensive conductivity $(\mu \mathrm{S} / \mathrm{cm})$ monitoring was carried out since March to July 2015, using a conductivity sensor emplaced in two artesian well, CAW01 and CAW02 using a sample frequency of 45 seconds; CAW01 site was monitored from March 2 to May 11, 2015 and the monitoring period for CAW02 was from May 11 to July 17, 61 days of monitoring for each.

Information of all earthquakes manifested in the period of March to July were acquired, particularly inside the territorial limits of the states of Guerrero and Oaxaca, Mexico, Figure 1: the data were downloaded of the page Web of the Seismological National (SSN) Service of Mexico, http://www2.ssn.unam.mx:8080/index.html.

In each artesian well the monitoring period was performed in three steps due to limited memory and battery capacity of the Data logger. Related to seismic data, each earthquake obtained was to less than 50 kilometers away, taking in consideration that both artesian wells are in a place with the highest seismicity of the region [37], [41]. For spatial distribution of seismic data, seismic event statistics obtained from the National Seismological Service (SSN: http://www2.ssn.unam.mx:8080/index.html) of Mexico, were imported to a geographic information system (GIS) to edit and depurate them. Every seismic event in the marine environment and those located beyond the distances of 50 kilometers were eliminated, thus obtaining a preliminary table. The seismic events resulting from the filtering were time synchronized graphically with the conductivity monitoring data by adding seismic events' series to conductivity series, replicating each step twice, one by each artesian well.

In natural environments, physical and biogeochemical processes called diel cycles influence the conductivity [54]. This measure is affected too by factors like temperature, mixing or recharge of different qualities of water because of the increases or decreases of ion concentration, or inclusive too mixing due to terrain compression or slight tilting of ground [9] caused by very light earthquakes which increase internal water flow in seismic areas [37]. These kind so fit references make difficult to identify how the electromagnetic frequency signals manifest in the results, even so the analysis of intensive monitoring conductivity $(\mu \mathrm{S} / \mathrm{cm})$ within the place selected could show interesting outcomes. In order to filter it, the conductivity data $(\mu \mathrm{S} / \mathrm{cm})$ were pre-processed and transformed using the first derivative of function $\left(x, y=f(x), y^{\prime}=f^{\prime}(x)\right)$ applying the equation Sine $(x),\left(-25^{*} X 3+\right.$ $48 * X 4-36 * X 5+16 * X 6-3 * X 7) / \rho t$, using a spread sheet calculus routine, Figure 2.

\section{Results}

Under aquatic environment through the intensive conductivity $(\mu \mathrm{S} / \mathrm{cm})$ monitoring a research were conducted in two places using a low-cost Data logger HOBO U24-001 sensor to measure the local natural conductivity as an indirect way to detect the electromagnetic natural energy coming from the interior of the Earth and its possible relation to earthquakes afterward manifested. According to the foregoing, from March 2 to July 17, 2015, two artesian wells were monitored, using a sampling frequency of 45 seconds. In order to find the possible relationship of natural energy that wanders around surroundings with local seismicity, 2012 records of seismic activity were downloaded of the page web of the Seismological National Service of Mexico(SSN),

http://www2.ssn.unam.mx:8080/index.html, were subsequently pre-processed according to the method abovementioned in previous paragraphs. Under this pre-process, as result 235 earthquakes were analyzed and confronted with the results of intensive conductivity monitoring data $(\mu \mathrm{S} / \mathrm{cm})$ obtained from two artesian well, by adding graphically, seismic events’ series to conductivity series. 
24 days serie of conductivity

Period: June 24 to July 17, 2015

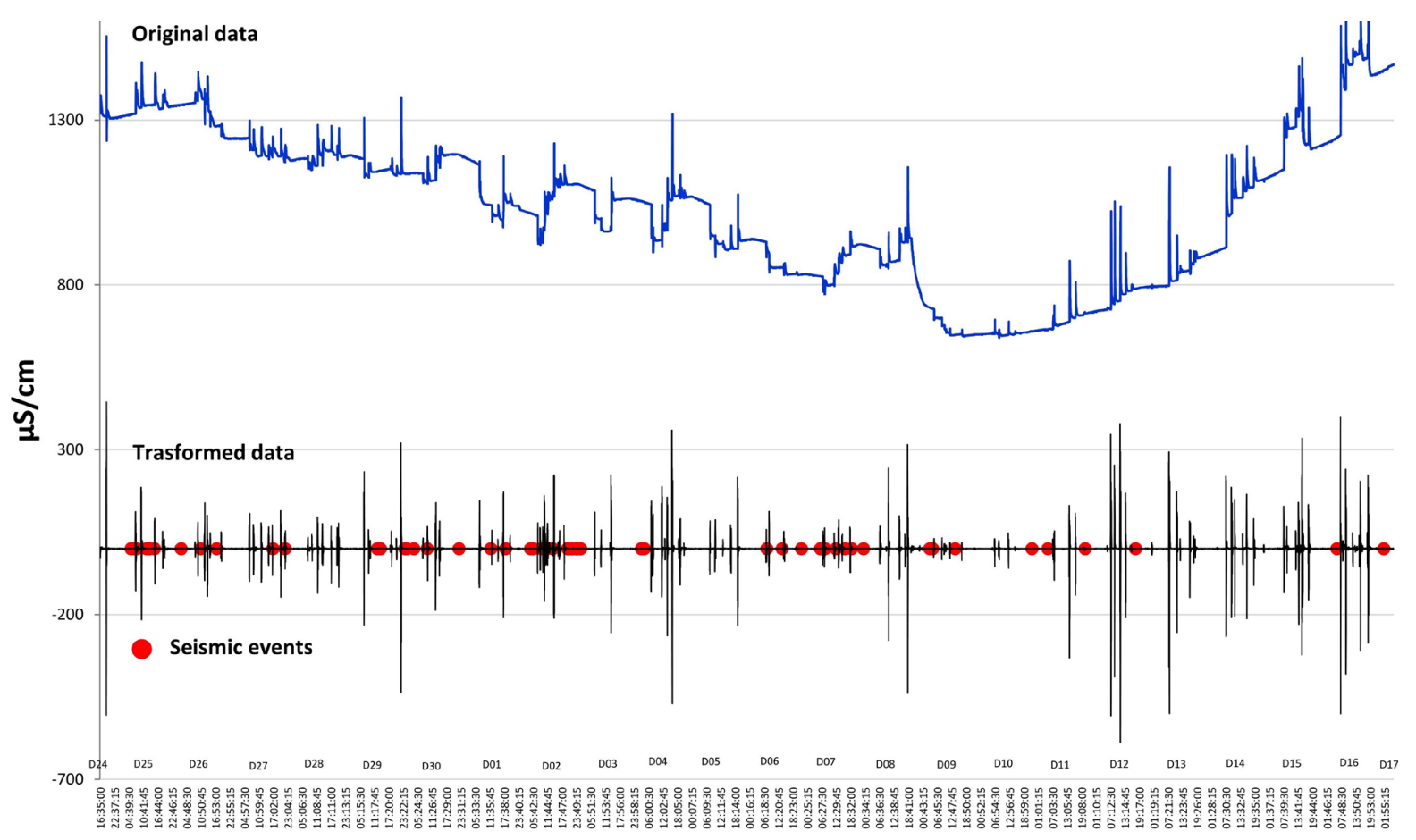

Figure 2. Mathematical pre-processed analysis of conductivity data (example): results of obtaining the first derivative.

The monitoring period of artesian well CAW01 started since March with three continuous stages, the first was of March 2 to 16; the second was of March 23 to April 15; and the third took place of April 20 to May 11. Related to artesian well CAW02 the first monitoring stage was started from May 11 to June 1; the second one started on June 1 to 24; and the last one was monitored from June 24 to July 17. The results of conductivity $(\mu \mathrm{S} / \mathrm{cm})$ monitoring in the three stages conducted in each artesian well are shown in high resolution graphs, Figures 3-8, and the possible previous and after relationship with the seismic activity per each period in both sites CAW01 andCAW02 is included in Tables 1-6 and debated in discussion section.

\section{Discussion}

Seismicity statistics show that the area designated for conductivity monitoring is the most active per square kilometer [37] [41], locally and taken the Data Logger as central reference for this, the $36.18 \%$ of the seismic events were located to the NW, nevertheless the seismic most important event registered during monitoring was located to the SE (M5.0; 06/25/2015; 5:31:46).

In relation to the linking between conductivity records and seismic activity during period of monitoring research, $61.64 \%$ of seismic events occurred prior conductivity oscillation versus $38.36 \%$ of early conductivity oscillation, Tables 1-6. The visual observation between graphs conductivity records and seismic activity by short times periods highlight that there is no clear correspondence about to conductivity oscillation and the seismic activity, however certain and subtle tendency was observed for long time period of monitoring, this trend corresponds to the aggregation of seismic event and conductivity oscillation, however is not frequent; this behavior can be seen it in Figure 6(1), Figure 7(2) and most undoubtedly in the Figure 8(1) and Figure 8(2).

From the 232 earthquakes studied, the statistics analysis shows that 159 earthquakes be like linked to conductivity oscillation, of which 98 events showed a significant variation in the conductivity preceding to the seismic events, these represent $61.63 \%$. 42 of 98 events (42.85\%) again were placed to the NW and 20 toward $\mathrm{E}$ (20.4\%). 61 events (38.36\%) occurred before of conductivity oscillations; of them, 18 events were located to the E and 18 toward NW. 

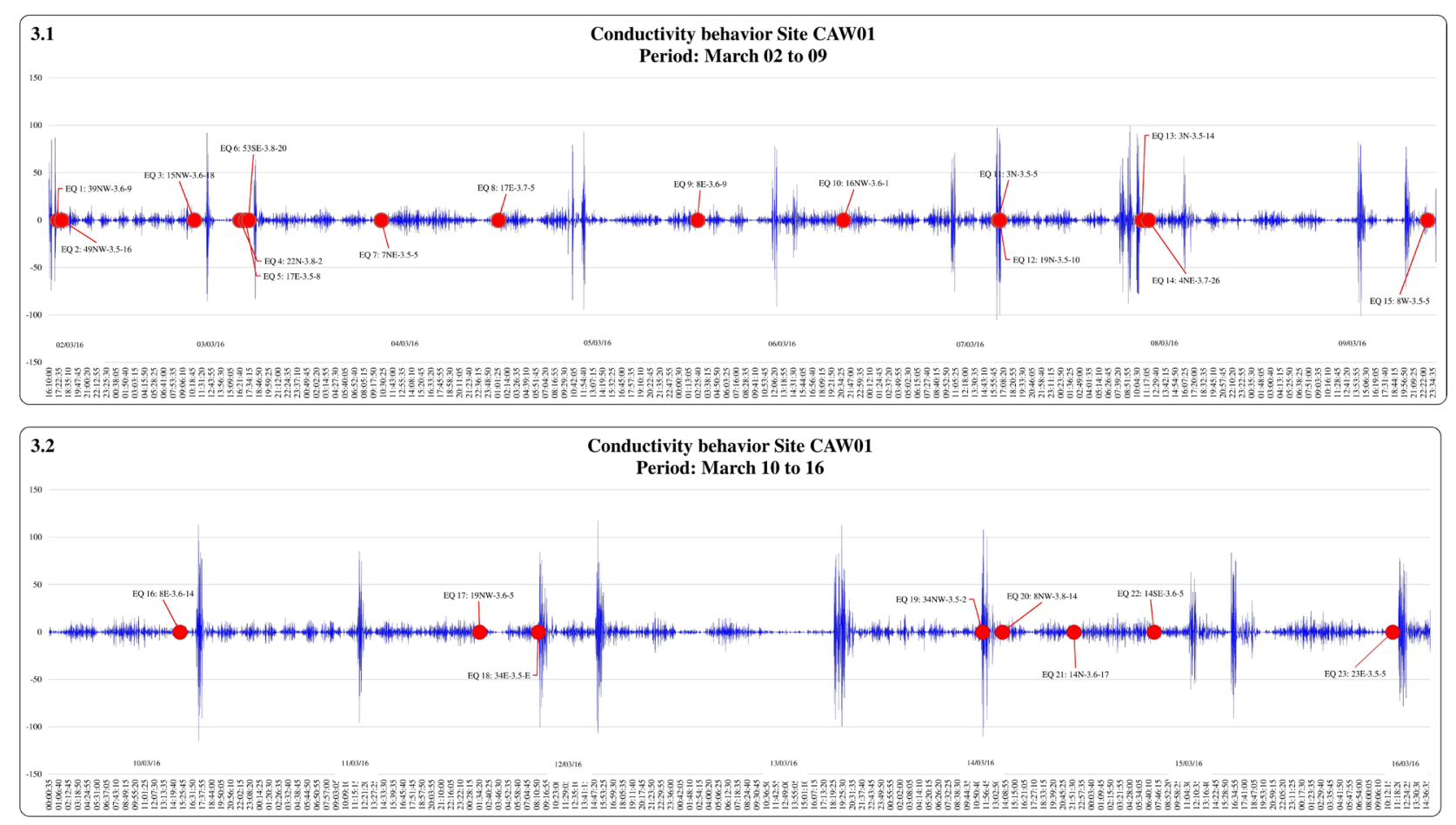

Figure 3. Conductivity behavior in artesian well CAW01 within the period of March 2 to 10 . During that period 23 earthquakes were manifested with an average magnitude of 3.6.Red dot (EQ 1: Cardinal point-wM-Depth).

Table 1. Analysis of seismic activity and the conductivity behavior in artesian well CAW01. 20 of 23 earthquakes were related with important oscillation conductivity, $50 \%$ of them display a prior oscillation and $50 \%$ early.

\begin{tabular}{|c|c|c|c|c|c|c|c|}
\hline \multirow{2}{*}{ Figure } & \multirow{2}{*}{ Event } & \multirow{2}{*}{ Cardinal point } & \multirow{2}{*}{ Distance } & \multirow{2}{*}{ Magnitude } & \multirow{2}{*}{ Depth } & \multicolumn{2}{|c|}{$\mu \mathrm{S} / \mathrm{cm}$ Oscillation } \\
\hline & & & & & & Previous & Later \\
\hline 3.1 & 1 & NW & 39 & 3.6 & 9 & $\bullet$ & \\
\hline 3.1 & 2 & NW & 49 & 3.5 & 16 & $\bullet$ & \\
\hline 3.1 & 3 & NW & 15 & 3.6 & 18 & & $\bullet$ \\
\hline 3.1 & 4 & $\mathrm{~N}$ & 22 & 3.8 & 2 & & $\bullet$ \\
\hline 3.1 & 5 & $\mathrm{E}$ & 17 & 3.5 & 8 & & $\bullet$ \\
\hline 3.1 & 6 & $\mathrm{SE}$ & 53 & 3.8 & 20 & & $\bullet$ \\
\hline 3.1 & 8 & $\mathrm{E}$ & 17 & 3.7 & 5 & & $\bullet$ \\
\hline 3.1 & 9 & $\mathrm{E}$ & 8 & 3.6 & 9 & & $\bullet$ \\
\hline 3.1 & 10 & NW & 16 & 3.6 & 1 & $\bullet$ & \\
\hline 3.1 & 11 & $\mathrm{~N}$ & 3 & 3.5 & 5 & $\bullet$ & \\
\hline 3.1 & 12 & $\mathrm{~N}$ & 19 & 3.5 & 10 & $\bullet$ & \\
\hline 3.1 & 13 & $\mathrm{~N}$ & 3 & 3.5 & 14 & $\bullet$ & \\
\hline 3.1 & 14 & $\mathrm{NE}$ & 4 & 3.7 & 26 & $\bullet$ & \\
\hline 3.1 & 15 & W & 8 & 3.5 & 5 & $\bullet$ & \\
\hline 3.2 & 16 & E & 8 & 3.6 & 14 & & • \\
\hline 3.2 & 17 & NW & 19 & 3.6 & 5 & & $\bullet$ \\
\hline 3.2 & 18 & E & 34 & 3.5 & 13 & & • \\
\hline 3.2 & 19 & NW & 34 & 3.5 & 2 & $\bullet$ & \\
\hline 3.2 & 20 & NW & 8 & 3.8 & 14 & • & \\
\hline 3.2 & 23 & E & 23 & 3.5 & 5 & & $\bullet$ \\
\hline
\end{tabular}


Table 2. Analysis of seismic activity and the conductivity behavior in artesian well CAW01. 40 of 48 earthquakes were related with important oscillation conductivity, $42.5 \%$ of them display a prior oscillation and $57.5 \%$ early.

\begin{tabular}{|c|c|c|c|c|c|c|c|}
\hline \multirow{2}{*}{ Figure } & \multirow{2}{*}{ Event } & \multirow{2}{*}{ Cardinal point } & \multirow{2}{*}{ Distance } & \multirow{2}{*}{ Magnitude } & \multirow{2}{*}{ Depth } & \multicolumn{2}{|c|}{$\mu \mathrm{S} / \mathrm{cm}$ Oscillation } \\
\hline & & & & & & Previous & Later \\
\hline 4.1 & 1 & E & 18.6 & 3.6 & 5 & & - \\
\hline 4.1 & 2 & E & 10 & 3.8 & 7 & & $\bullet$ \\
\hline 4.1 & 3 & E & 9 & 4.2 & 14 & $\bullet$ & \\
\hline 4.1 & 4 & NW & 20.8 & 3.5 & 6 & & • \\
\hline 4.1 & 7 & $\mathrm{~N}$ & 15.7 & 3.7 & 20 & $\bullet$ & \\
\hline 4.1 & 6 & $\mathrm{E}$ & 28.2 & 3.6 & 80 & $\bullet$ & \\
\hline 4.1 & 7 & NW & 16.3 & 3.5 & 29 & & $\bullet$ \\
\hline 4.2 & 8 & $\mathrm{SE}$ & 8.3 & 3.8 & 10 & & • \\
\hline 4.2 & 9 & $\mathrm{E}$ & 7.1 & 3.8 & 13 & $\bullet$ & \\
\hline 4.2 & 10 & E & 24 & 3.5 & 3 & & $\bullet$ \\
\hline 4.2 & 11 & NW & 11.2 & 3.8 & 36 & & • \\
\hline 4.2 & 12 & SE & 12 & 3.8 & 7 & & • \\
\hline 4.2 & 13 & $\mathrm{NE}$ & 30.1 & 3.7 & 25 & & $\bullet$ \\
\hline 4.2 & 14 & $\mathrm{E}$ & 13.3 & 3.7 & 9 & • & \\
\hline 4.2 & 15 & NW & 33.8 & 3.5 & 3 & • & \\
\hline 4.2 & 17 & NW & 37.6 & 3.6 & 24 & • & \\
\hline 4.2 & 18 & E & 2.9 & 3.6 & 15 & & • \\
\hline 4.2 & 19 & $\mathrm{NE}$ & 36.1 & 3.6 & 5 & • & \\
\hline 4.2 & 20 & $\mathrm{~N}$ & 11.9 & 3.6 & 12 & • & \\
\hline 4.2 & 21 & $\mathrm{~N}$ & 3.4 & 3.5 & 14 & • & \\
\hline 4.2 & 22 & $\mathrm{SE}$ & 5.3 & 3.8 & 3 & • & \\
\hline 4.2 & 24 & NW & 45 & 3.9 & 5 & & • \\
\hline 4.2 & 26 & $\mathrm{NE}$ & 30.5 & 3.9 & 9 & & • \\
\hline 4.2 & 29 & $\mathrm{SE}$ & 61.7 & 4 & 11 & & • \\
\hline 4.2 & 27 & NW & 43.4 & 3.6 & 7 & • & \\
\hline 4.3 & 29 & NW & 41.8 & 3.7 & 20 & • & \\
\hline 4.3 & 30 & $\mathrm{~N}$ & 16.8 & 3.6 & 16 & • & \\
\hline 4.3 & 31 & NW & 44.3 & 3.5 & 8 & & • \\
\hline 4.3 & 33 & $\mathrm{~N}$ & 13.3 & 3.6 & 16 & & • \\
\hline 4.3 & 36 & $\mathrm{E}$ & 9 & 3.6 & 3 & & • \\
\hline 4.3 & 37 & E & 9 & 4 & 11 & $\bullet$ & \\
\hline 4.3 & 39 & $\mathrm{SE}$ & 65.4 & 4 & 14 & & • \\
\hline 4.3 & 40 & E & 40.8 & 4.1 & 10 & & • \\
\hline 4.3 & 42 & $\mathrm{NE}$ & 8 & 3.7 & 13 & & • \\
\hline 4.3 & 43 & $\mathrm{NE}$ & 10.5 & 3.6 & 12 & & • \\
\hline 4.3 & 44 & NW & 47.6 & 3.6 & 4 & & • \\
\hline 4.3 & 45 & NW & 49.6 & 3.6 & 15 & & • \\
\hline 4.3 & 46 & NW & 28.9 & 3.5 & 6 & & • \\
\hline 4.3 & 47 & NW & 44.1 & 3.9 & 9 & • & \\
\hline 4.3 & 48 & $\mathrm{E}$ & 12.2 & 3.6 & 10 & • & \\
\hline
\end{tabular}


Table 3. Analysis of seismic activity and the conductivity behavior in artesian well CAW01. 25 of 46 earthquakes were related with important oscillation conductivity, $60 \%$ of them display a prior oscillation and $40 \%$ early.

\begin{tabular}{|c|c|c|c|c|c|c|c|}
\hline \multirow{2}{*}{ Figure } & \multirow{2}{*}{ Event } & \multirow{2}{*}{ Cardinal point } & \multirow{2}{*}{ Distance } & \multirow{2}{*}{ Magnitude } & \multirow{2}{*}{ Depth } & \multicolumn{2}{|c|}{$\mu \mathrm{S} / \mathrm{cm}$ Oscillation } \\
\hline & & & & & & Previous & Later \\
\hline 5.1 & 1 & $\mathrm{~W}$ & 15 & 3.6 & 5 & $\bullet$ & \\
\hline 5.1 & 5 & $\mathrm{NE}$ & 11 & 3.5 & 13 & & $\bullet$ \\
\hline 5.1 & 6 & NW & 34 & 3.8 & 29 & $\bullet$ & \\
\hline 5.1 & 7 & $\mathrm{E}$ & 28 & 3.5 & 5 & $\bullet$ & \\
\hline 5.1 & 8 & $\mathrm{E}$ & 24 & 3.5 & 10 & $\bullet$ & \\
\hline 5.1 & 13 & $\mathrm{E}$ & 16 & 3.5 & 5 & & $\bullet$ \\
\hline 5.1 & 14 & $\mathrm{E}$ & 15 & 3.5 & 5 & $\bullet$ & \\
\hline 5.1 & 15 & $\mathrm{E}$ & 26 & 3.6 & 10 & $\bullet$ & \\
\hline 5.1 & 16 & $\mathrm{E}$ & 42 & 3.5 & 21 & $\bullet$ & \\
\hline 5.1 & 17 & NW & 43 & 3.6 & 2 & & $\bullet$ \\
\hline 5.1 & 18 & NW & 20 & 4.7 & 27 & $\bullet$ & \\
\hline 5.1 & 19 & NW & 26 & 3.6 & 8 & $\bullet$ & \\
\hline 5.1 & 20 & NW & 24 & 3.5 & 11 & $\bullet$ & \\
\hline 5.1 & 21 & $\mathrm{~W}$ & 4 & 3.5 & 8 & $\bullet$ & \\
\hline 5.2 & 22 & $\mathrm{SE}$ & 7 & 3.7 & 5 & & $\bullet$ \\
\hline 5.2 & 25 & $\mathrm{~N}$ & 24 & 3.8 & 21 & & $\bullet$ \\
\hline 5.2 & 26 & NW & 26 & 3.5 & 2 & & $\bullet$ \\
\hline 5.2 & 27 & $\mathrm{E}$ & 13 & 3.5 & 7 & $\bullet$ & \\
\hline 5.2 & 28 & $\mathrm{E}$ & 5 & 3.6 & 9 & & $\bullet$ \\
\hline 5.2 & 29 & NW & 34 & 3.7 & 19 & & $\bullet$ \\
\hline 5.2 & 30 & NW & 42 & 3.9 & 5 & $\bullet$ & \\
\hline 5.2 & 31 & $\mathrm{~W}$ & 1 & 3.5 & 15 & $\bullet$ & \\
\hline 5.2 & 33 & $\mathrm{SE}$ & 11 & 3.5 & 3 & & $\bullet$ \\
\hline 5.2 & 34 & $\mathrm{SE}$ & 15 & 3.7 & 6 & & • \\
\hline 5.2 & 35 & $\mathrm{NE}$ & 8 & 3.7 & 11 & $\bullet$ & \\
\hline 5.3 & 37 & NW & 20 & 3.5 & 12 & & • \\
\hline 5.3 & 38 & NW & 17 & 3.5 & 16 & & • \\
\hline 5.3 & 40 & $\mathrm{SE}$ & 11 & 3.7 & 5 & • & \\
\hline 5.3 & 41 & $\mathrm{~N}$ & 36 & 3.5 & 5 & • & \\
\hline 5.3 & 43 & E & 9 & 3.7 & 4 & • & \\
\hline 5.3 & 44 & NW & 36 & 3.5 & 22 & • & \\
\hline 5.3 & 45 & $\mathrm{NE}$ & 7 & 3.8 & 13 & & • \\
\hline 5.3 & 46 & SE & 8 & 3.8 & 11 & & • \\
\hline
\end{tabular}


Table 4. Analysis of seismic activity and the conductivity behavior in artesian well CAW02. 23 of 36 earthquakes were related with important oscillation conductivity, $78.3 \%$ of them display a prior oscillation and $21.7 \%$ early.

\begin{tabular}{|c|c|c|c|c|c|c|c|}
\hline \multirow{2}{*}{ Figure } & \multirow{2}{*}{ Event } & \multirow{2}{*}{ Cardinal point } & \multirow{2}{*}{ Distance } & \multirow{2}{*}{ Magnitude } & \multirow{2}{*}{ Depth } & \multicolumn{2}{|c|}{$\mu \mathrm{S} / \mathrm{cm}$ Oscillation } \\
\hline & & & & & & Previous & Later \\
\hline 6.1 & 1 & NW & 13 & 3.6 & 5 & $\bullet$ & \\
\hline 6.1 & 2 & NW & 35 & 3.6 & 31 & $\bullet$ & \\
\hline 6.2 & 9 & NW & 52 & 3.8 & 16 & $\bullet$ & \\
\hline 6.2 & 10 & NW & 52 & 3.8 & 33 & $\bullet$ & \\
\hline 6.2 & 11 & $\mathrm{SE}$ & 8 & 3.5 & 3 & & $\bullet$ \\
\hline 6.2 & 12 & $\mathrm{E}$ & 20 & 3.6 & 5 & & $\bullet$ \\
\hline 6.2 & 13 & NW & 47 & 3.7 & 5 & $\bullet$ & \\
\hline 6.2 & 14 & $\mathrm{~W}$ & 3 & 3.5 & 12 & $\bullet$ & \\
\hline 6.2 & 15 & NW & 24 & 3.6 & 10 & $\bullet$ & \\
\hline 6.2 & 16 & $\mathrm{E}$ & 15 & 3.8 & 12 & & $\bullet$ \\
\hline 6.2 & 17 & NW & 16 & 4.1 & 4 & $\bullet$ & \\
\hline 6.2 & 18 & $\mathrm{~N}$ & 8 & 3.7 & 13 & $\bullet$ & \\
\hline 6.3 & 22 & $\mathrm{E}$ & 3 & 3.6 & 14 & $\bullet$ & \\
\hline 6.3 & 23 & NW & 8 & 3.8 & 10 & • & \\
\hline 6.3 & 24 & E & 11 & 3.6 & 10 & $\bullet$ & \\
\hline 6.3 & 25 & NW & 33 & 3.8 & 7 & • & \\
\hline 6.3 & 26 & $\mathrm{~W}$ & 6 & 3.5 & 12 & & $\bullet$ \\
\hline 6.3 & 27 & NW & 49 & 3.7 & 5 & $\bullet$ & \\
\hline 6.3 & 28 & NW & 8 & 3.7 & 14 & & $\bullet$ \\
\hline 6.3 & 29 & SE & 18 & 3.6 & 5 & $\bullet$ & \\
\hline 6.3 & 30 & NW & 44 & 3.8 & 18 & $\bullet$ & \\
\hline 6.3 & 31 & NW & 36 & 3.6 & 13 & $\bullet$ & \\
\hline 6.3 & 33 & NW & 39 & 3.6 & 29 & • & \\
\hline
\end{tabular}

Table 5. Analysis of seismic activity and the conductivity behavior in artesian well CAW02. 19 of 27 earthquakes were related with important oscillation conductivity, $73.7 \%$ of them display a prior oscillation and $26.3 \%$ early.

\begin{tabular}{|c|c|c|c|c|c|c|c|}
\hline \multirow{2}{*}{ Figure } & \multirow{2}{*}{ Event } & \multirow{2}{*}{ Cardinal point } & \multirow{2}{*}{ Distance } & \multirow{2}{*}{ Magnitude } & \multirow{2}{*}{ Depth } & \multicolumn{2}{|c|}{$\mu \mathrm{S} / \mathrm{cm}$ Oscillation } \\
\hline & & & & & & Previous & Later \\
\hline 7.1 & 3 & NW & 55 & 3.8 & 38 & $\bullet$ & \\
\hline 7.1 & 4 & $\mathrm{NE}$ & 34 & 4 & 5 & & $\bullet$ \\
\hline 7.1 & 5 & $\mathrm{NE}$ & 32 & 3.6 & 5 & & $\bullet$ \\
\hline 7.1 & 6 & NW & 13 & 3.6 & 30 & & $\bullet$ \\
\hline 7.1 & 7 & $\mathrm{NE}$ & 32 & 3.6 & 7 & $\bullet$ & \\
\hline 7.1 & 8 & $\mathrm{NE}$ & 34 & 3.5 & 2 & $\bullet$ & \\
\hline 7.1 & 9 & NW & 44 & 4 & 6 & $\bullet$ & \\
\hline 7.2 & 12 & $\mathrm{NE}$ & 32 & 3.9 & 13 & & $\bullet$ \\
\hline
\end{tabular}




\section{Continued}

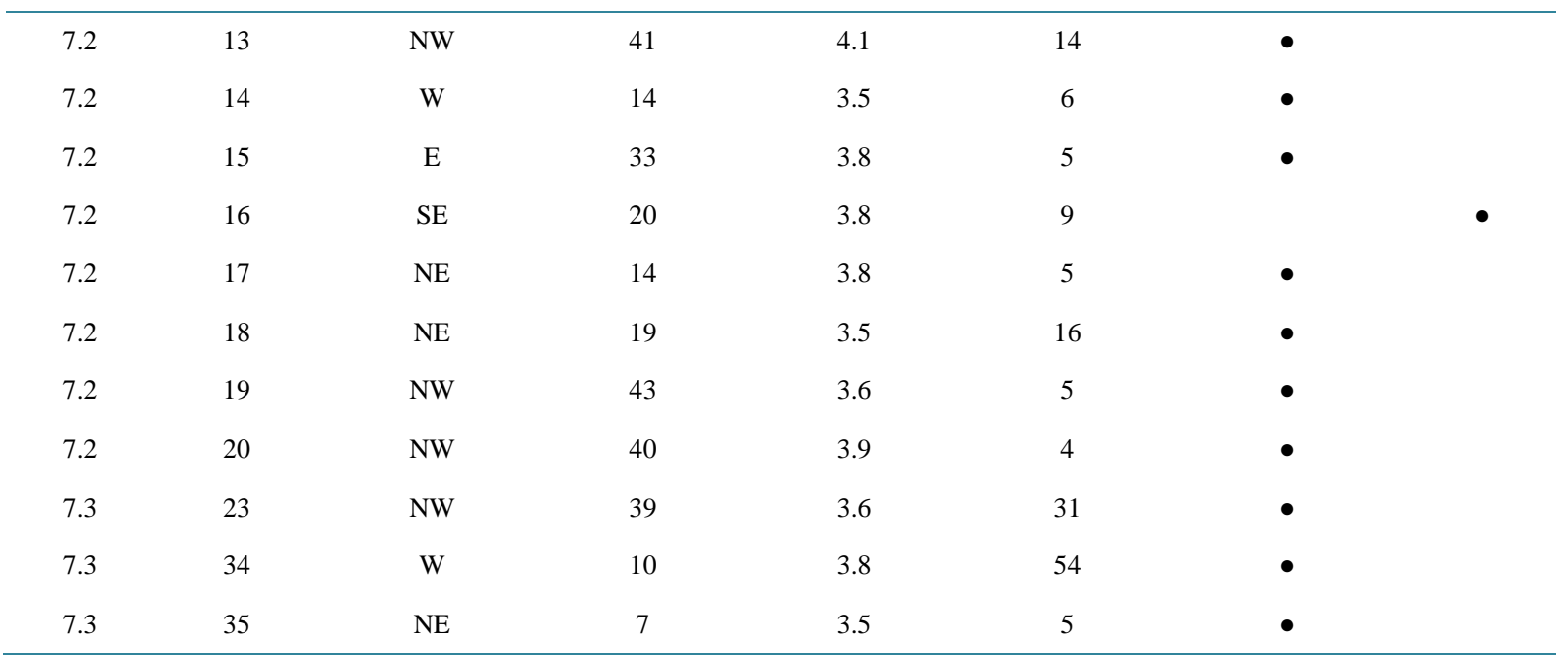

Table 6. Analysis of seismic activity and the conductivity behavior in artesian well CAW02. 32 of 55 earthquakes were related with important oscillation conductivity, $75 \%$ of them display a prior oscillation and $25 \%$ early.

\begin{tabular}{|c|c|c|c|c|c|c|c|}
\hline \multirow{2}{*}{ Figure } & \multirow{2}{*}{ Event } & \multirow{2}{*}{ Cardinal point } & \multirow{2}{*}{ Distance } & \multirow{2}{*}{ Magnitude } & \multirow{2}{*}{ Depth } & \multicolumn{2}{|c|}{$\mu \mathrm{S} / \mathrm{cm}$ Oscillation } \\
\hline & & & & & & Previous & Later \\
\hline 8.1 & 1 & SE & 17 & 5 & 16 & $\bullet$ & \\
\hline 8.1 & 2 & $\mathrm{NE}$ & 17 & 3.6 & 56 & $\bullet$ & \\
\hline 8.1 & 3 & $\mathrm{NE}$ & 7 & 3.6 & 34 & $\bullet$ & \\
\hline 8.1 & 4 & $\mathrm{NE}$ & 21 & 3.7 & 72 & $\bullet$ & \\
\hline 8.1 & 5 & $\mathrm{NE}$ & 16 & 3.6 & 15 & $\bullet$ & \\
\hline 8.1 & 6 & $\mathrm{E}$ & 11 & 3.5 & 30 & $\bullet$ & \\
\hline 8.1 & 7 & $\mathrm{SE}$ & 15 & 3.6 & 30 & $\bullet$ & \\
\hline 8.1 & 9 & $\mathrm{NE}$ & 28 & 3.6 & 13 & & $\bullet$ \\
\hline 8.1 & 10 & NW & 25 & 3.9 & 12 & $\bullet$ & \\
\hline 8.1 & 13 & $\mathrm{NE}$ & 18 & 3.5 & 25 & & $\bullet$ \\
\hline 8.1 & 14 & $\mathrm{E}$ & 23 & 3.5 & 5 & & $\bullet$ \\
\hline 8.1 & 15 & NW & 20 & 3.5 & 28 & $\bullet$ & \\
\hline 8.1 & 16 & NW & 50 & 3.9 & 16 & $\bullet$ & \\
\hline 8.1 & 17 & $\mathrm{NE}$ & 15 & 3.5 & 12 & $\bullet$ & \\
\hline 8.1 & 21 & NW & 7 & 3.7 & 14 & $\bullet$ & \\
\hline 8.2 & 22 & NW & 12 & 3.8 & 13 & & $\bullet$ \\
\hline 8.2 & 23 & NW & 26 & 3.6 & 27 & & $\bullet$ \\
\hline 8.2 & 24 & NW & 10 & 3.8 & 9 & $\bullet$ & \\
\hline 8.2 & 25 & NW & 15 & 3.6 & 5 & $\bullet$ & \\
\hline 8.2 & 26 & NW & 25 & 4.1 & 5 & • & \\
\hline 8.2 & 27 & E & 34 & 3.6 & 29 & • & \\
\hline
\end{tabular}




\section{Continued}

\begin{tabular}{|c|c|c|c|c|c|c|c|}
\hline 8.2 & 28 & $\mathrm{E}$ & 37 & 3.7 & 26 & • & \\
\hline 8.2 & 29 & $\mathrm{E}$ & 38 & 3.9 & 20 & • & \\
\hline 8.2 & 30 & E & 30 & 3.7 & 11 & • & \\
\hline 8.2 & 35 & SW & 2 & 3.7 & 12 & & 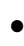 \\
\hline 8.2 & 36 & $\mathrm{E}$ & 25 & 4 & 6 & & $\bullet$ \\
\hline 8.2 & 47 & NW & 39 & 3.6 & 30 & $\bullet$ & \\
\hline 8.2 & 48 & $\mathrm{SE}$ & 19 & 3.6 & 16 & $\bullet$ & \\
\hline 8.3 & 52 & $\mathrm{NE}$ & 41 & 3.8 & 29 & • & \\
\hline 8.3 & 53 & SE & 10 & 308 & 20 & $\bullet$ & \\
\hline 8.3 & 54 & NW & 50 & 3.7 & 29 & & $\bullet$ \\
\hline 8.3 & 55 & $\mathrm{NE}$ & 43 & 3.8 & 57 & • & \\
\hline
\end{tabular}
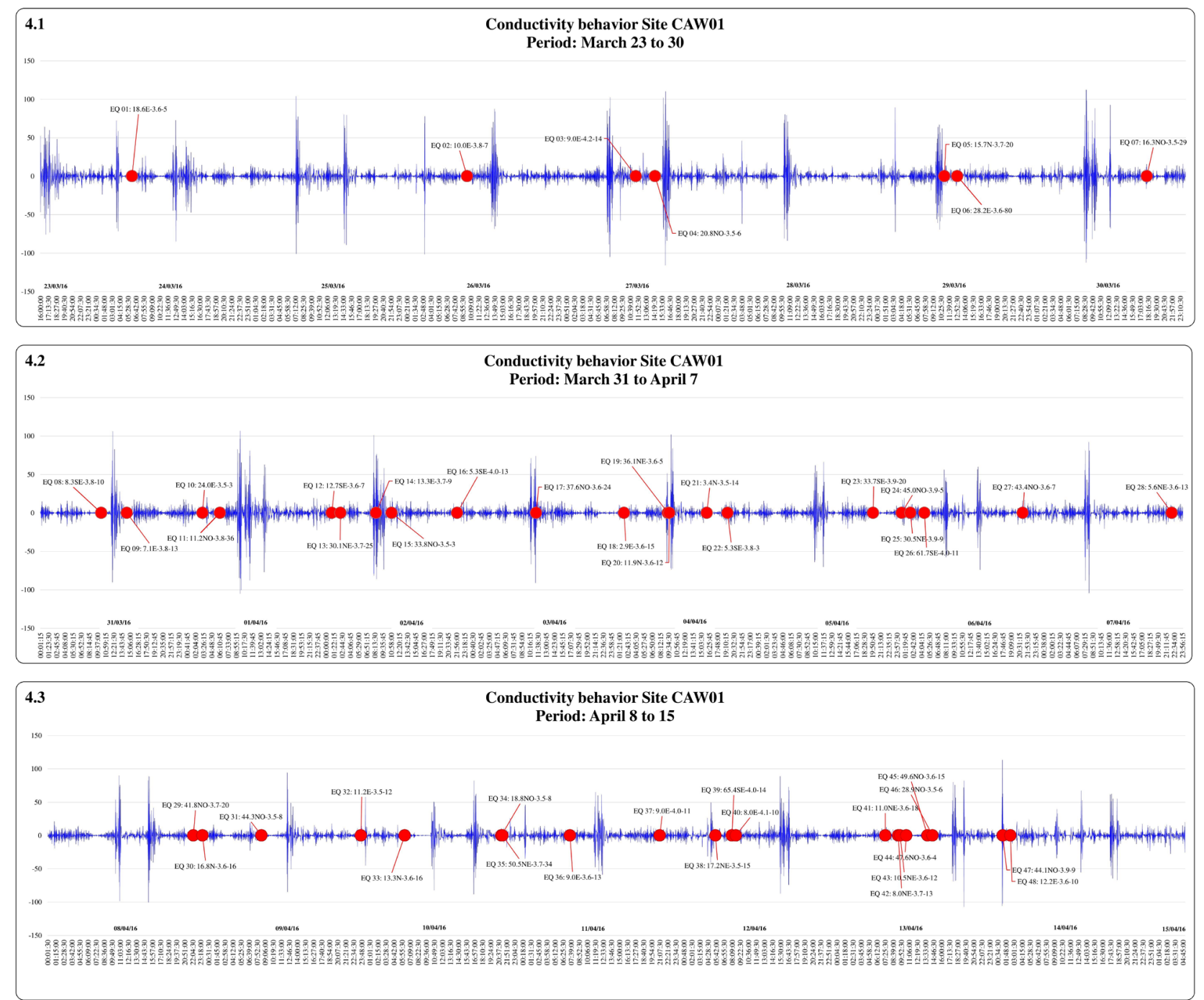

Figure 4. Conductivity behavior in artesian well CAW01 within the period of March 23 to April 15. During that period 48 earthquakes were manifested with an average magnitude of 3.7. Red dot (EQ 1: Cardinal point-wM-Depth). 

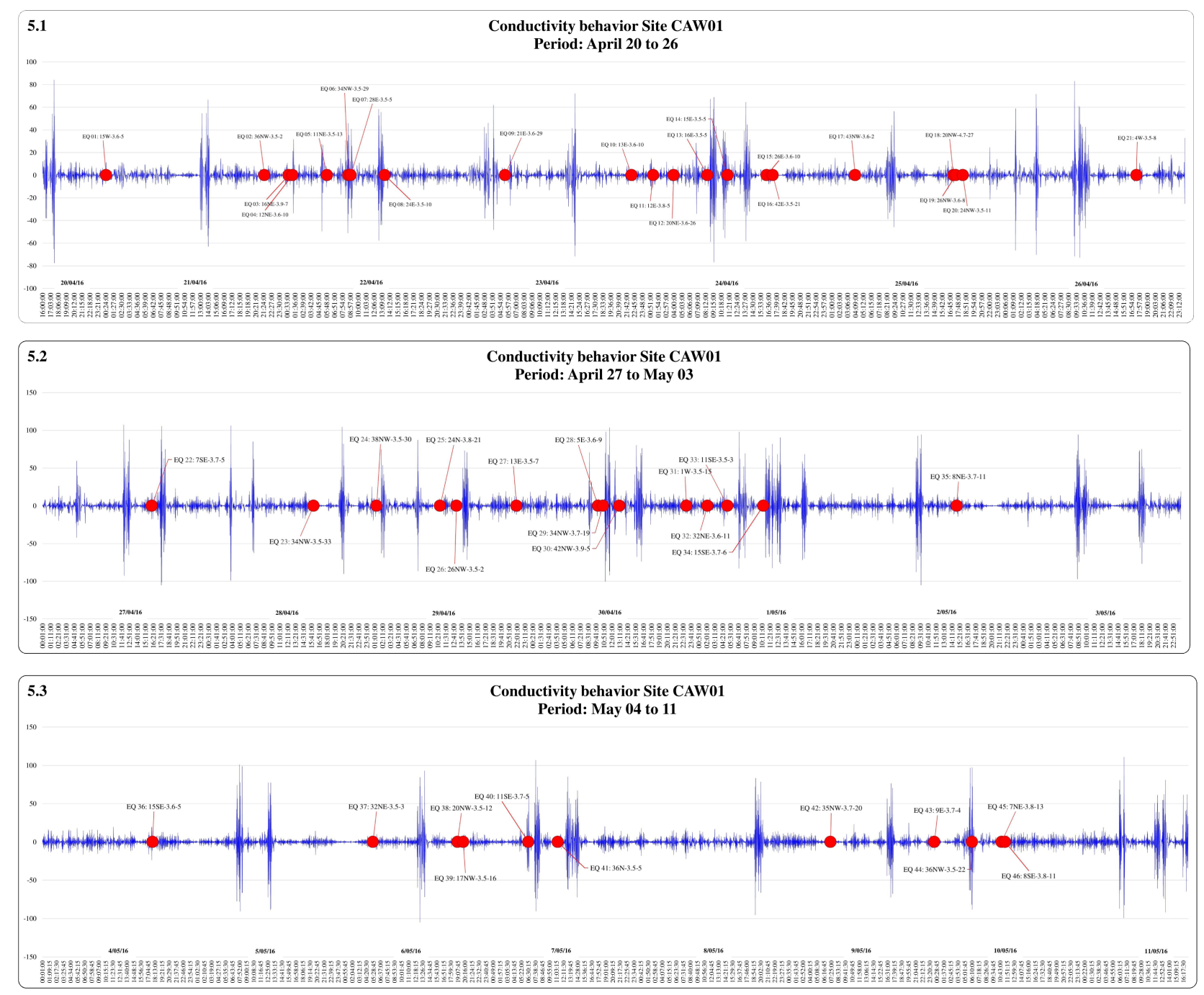

Figure 5. Conductivity behavior in artesian well CAW01 within the period of April 20 to May 11. During that period 46 earthquakes were manifested with an average magnitude of 3.6. Red dot (EQ 1: Cardinal point-wM-Depth).

In terms of the conductivity behavior observed, the graph without data transformation of the artesian wells CAW01 and CAW02 data showed significant differences between them. The CAW01 site showed drops in conductivity with very marked fluctuation, the average values were 14.12 to $1203.6 \mu \mathrm{S} / \mathrm{cm}$, Figure 9; while the site CAW02 oscillations were less marked, the oscillation value was 610 to $1700 \mu \mathrm{S} / \mathrm{cm}$, however the general behavior of the data appears to be odd, Figure 10.

In both graphs the data conductivity trending showed-up to three diurnal variations, either decreasing or increasing the conductivity, this behavior may point out that the internal flow of water is extremely fast indicating a vigorous recharge. Some possible explanations for these anomalies could be the proximity of the sampling site to a lagoon or groundwater stream, although several of conductivity oscillations are more than normally of those expected in one day.

Another possible explanation is the frequent seismic activity in the area where are the sampling sites because of slight seismic movements or tremors [55]-[57], these movements also cause possible ground compression, like squeezing a sponge [9] [37], which is reflected in sudden changes in water chemistry by apparent flows of groundwater, this directly impacts the amount of ions and so reflected in conductivity oscillations.

Likewise, the atypical variations in conductivity may be associated with electromagnetic energy wandering in the surroundings [5] [46] [47] [58], which interacts with ionic local particles move them away of the conductivity sensor or also, triggering an interference to the conductivity sensor's operation. Finally, the use of artesian 

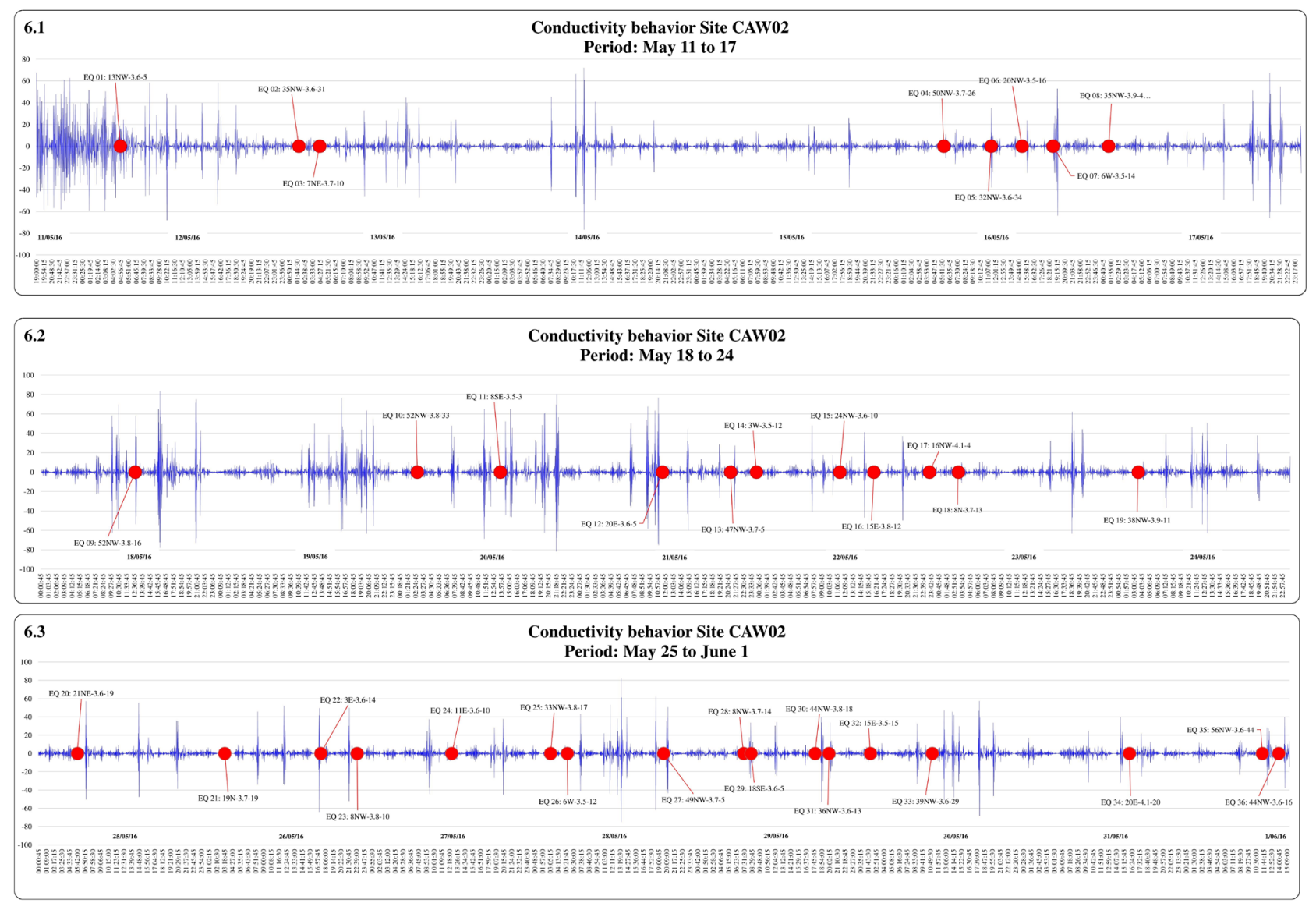

Figure 6. Conductivity behavior in artesian well CAW02 within the period of May 11 to June the first. During that period 36 earthquakes were manifested with an average magnitude of 3.7. Red dot (EQ 1: Cardinal point-wM-Depth).

wells that their owners do to their household domestic chores can be others factors that promote changes in conductivity.

In accord with data plotted no transformed, Figure 10, from June 24 to July 9 a downward trend of conductivity was maintained and this period and is associated with a previous and important seismic activity; after that, seismic activity decrease, afterwards the tendency of conductivity oscillation was slightly again.

The partial analysis of a multiple 24-hour data series sets of site CAW02no transformed, during 16 days (June 24 to July 17), and the total monitoring period of CAW01 (March 2 to May 11, 61 days) and CAW02 (May 12 to July 17, 61 days) of 2015, show interesting divergence. In the first series of data the conductivity behavior shows noticeable oscillations between 7:00 to 22:00 hours, Figure 11, after this period, the oscillations decrease. This data conduct point to the possible human factor is causing the variability, but this it is not very clear; despite of coincidences between some series the oscillations' data had a wide range of conductivity values: 600 to $1700 \mu \mathrm{S} / \mathrm{cm}$.

The analysis of total data monitoring through 61 days of sites CAW01 and CAW02 without data transformation, show the subtle tendency between seismic event aggregation and conductivity oscillation mentioned and referred in Figure 6 (1), Figure 7 (2), Figure 8 (1) and Figure 8 (2), this pattern enhance the possible correspondence between the previous conductivity oscillation and later seismic activity. From March 2 to May 11 (CAW01), Figure 12, at the beginning of the graph there is an increasing of the conductivity values whose positive trend was maintained until half of the monitoring period, afterward the trend was negative with very erratic behavior that keep up until the end of the sampling period. During the positive trend of conductivity the presence of seismic events was more dispersed, but when the negative trend of the data starts, showed a higher concentration of seismic events which is maintained afterwards.

Of May 11 to July 17 (CAW02) the graph with data no transformed shows three major fluctuations that grew 

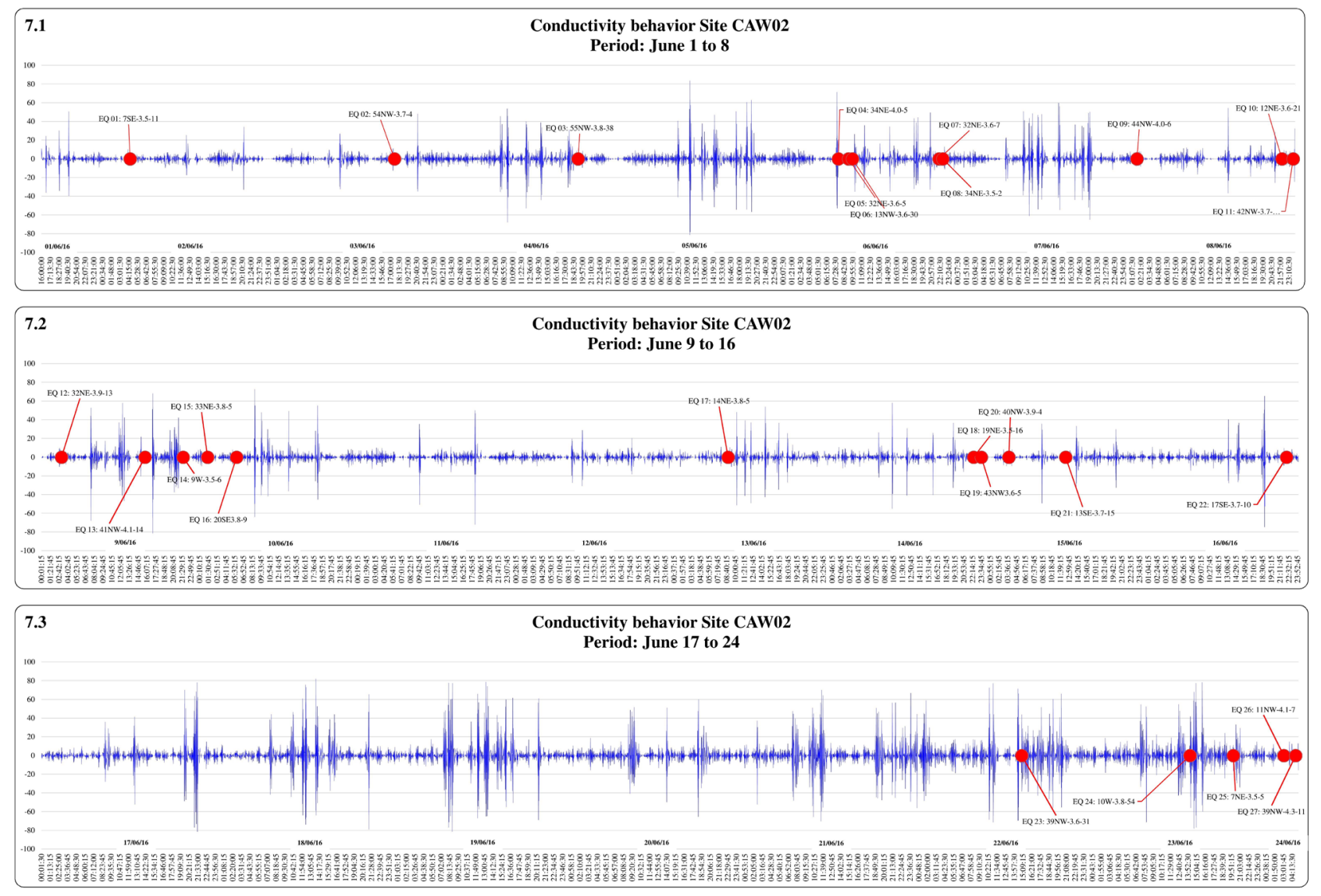

Figure 7. Conductivity behavior in artesian well CAW02 within the period of June 1 to 24 . During that period 27 earthquakes were manifested with an average magnitude of 3.6. Red dot (EQ 1: Cardinal point-wM-Depth).

over time, the average conductivity records were close to $600 \mu \mathrm{S} / \mathrm{cm}$ before the first seismic activity oscillation, Figure 13. As the number of earthquakes decreased conductivity increased, the highest values grew-up to 1700 $\mu \mathrm{S} / \mathrm{cm}$; during the period from June 15 to July 17 this behavior was more evident. When compared the graphs of 24 hours data series and the 61 days data series, the difference between them are outstanding, last one shows possible long term oscillations associate to the earthquakes' manifestation, therefore the future systematic long term monitoring of any manifestation of direct energy (electromagnetic fields) or indirectly (conductivity) can contribute more to ratify the possible presence of long time phenomena observed in this research in order to determine if this behavior is specific of Pinotepa Nacional surroundings or could be identified within other subduction zones.

Only part of the seismic events manifested in the period of May 11 to July 17 in this analysis were processed (118 earthquakes, Figure 13), those considered most likely to have some correspondence with the conductivity fluctuations records, particularly those occurred to less than 50 kilometers away, considering that the sites of monitoring were located in a place with the highest seismicity of the region; in fact the total number of seismic events occurred between of Guerrero and Oaxaca estates limits during 61 days were 724 distributed at different distances around the Dada Logger conductivity sensor, with a magnitude average of 3.8, some of them at 450 kilometers away.

\section{Conclusions}

Statistically the area designated for conductivity monitoring of Pinotepa Nacional between the border of Guerrero and Oaxaca, Mexico, is the most active per square kilometer with three seismic events per day with average of $3.8 \mathrm{Mw}$. 

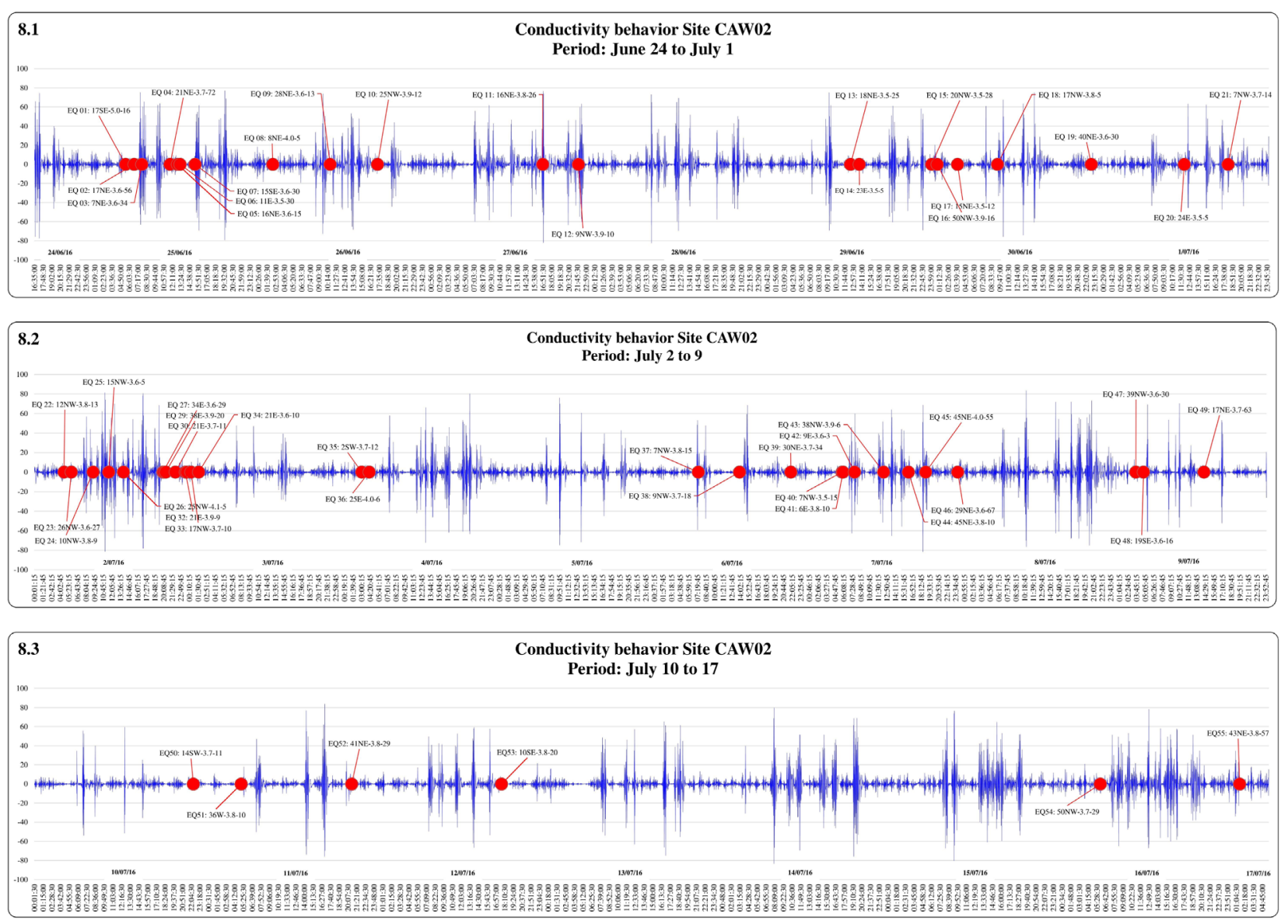

Figure 8. Conductivity behavior in artesian well CAW02 within the period of June 24 to July 17. During that period 55 earthquakes were manifested with an average magnitude of 3.7. Red dot (EQ 1: Cardinal point-wM-Depth).

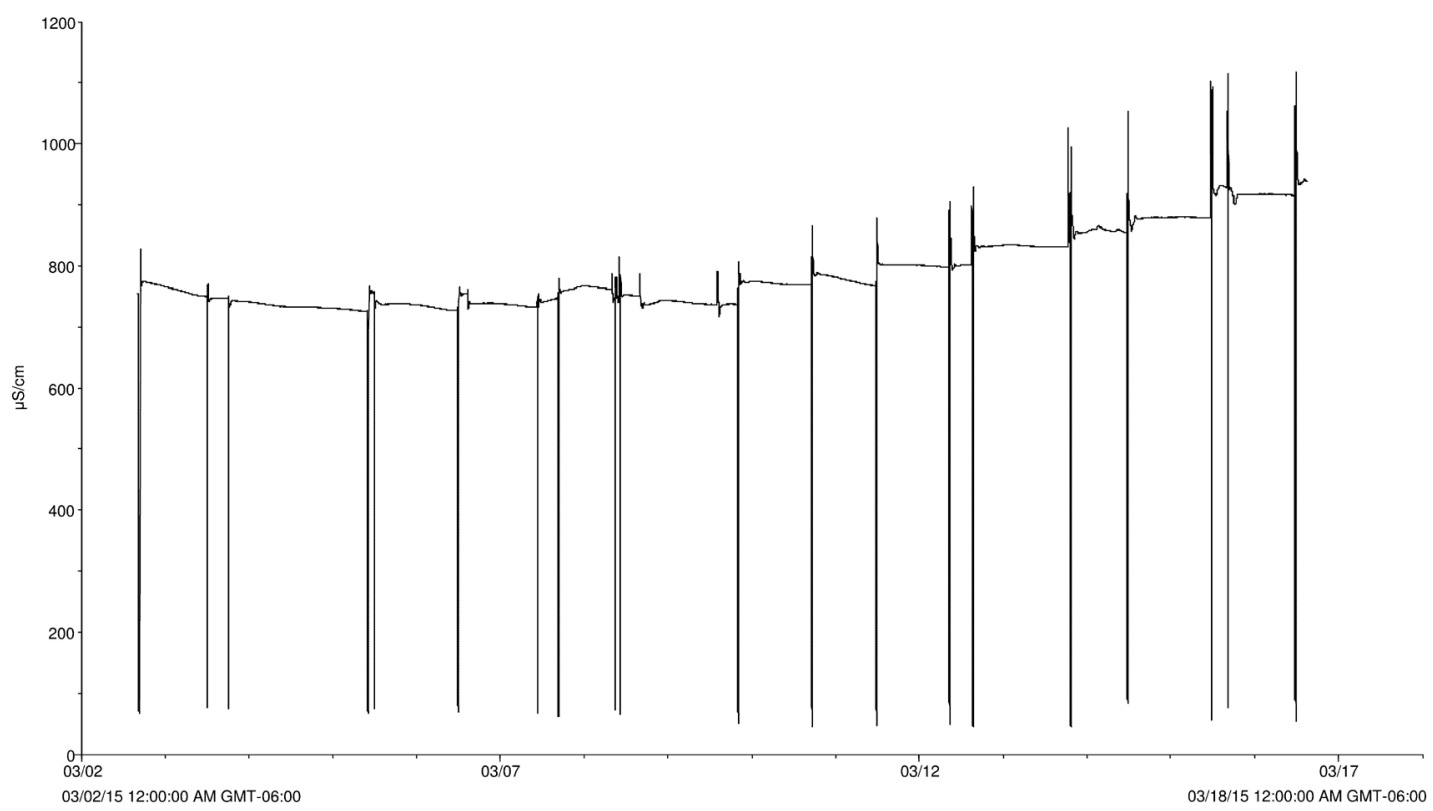

Figure 9. General behavior conductivity observed in the CAW01 site. This monitoring data correspond to a period of March 2 to 15 of 2015 only. 


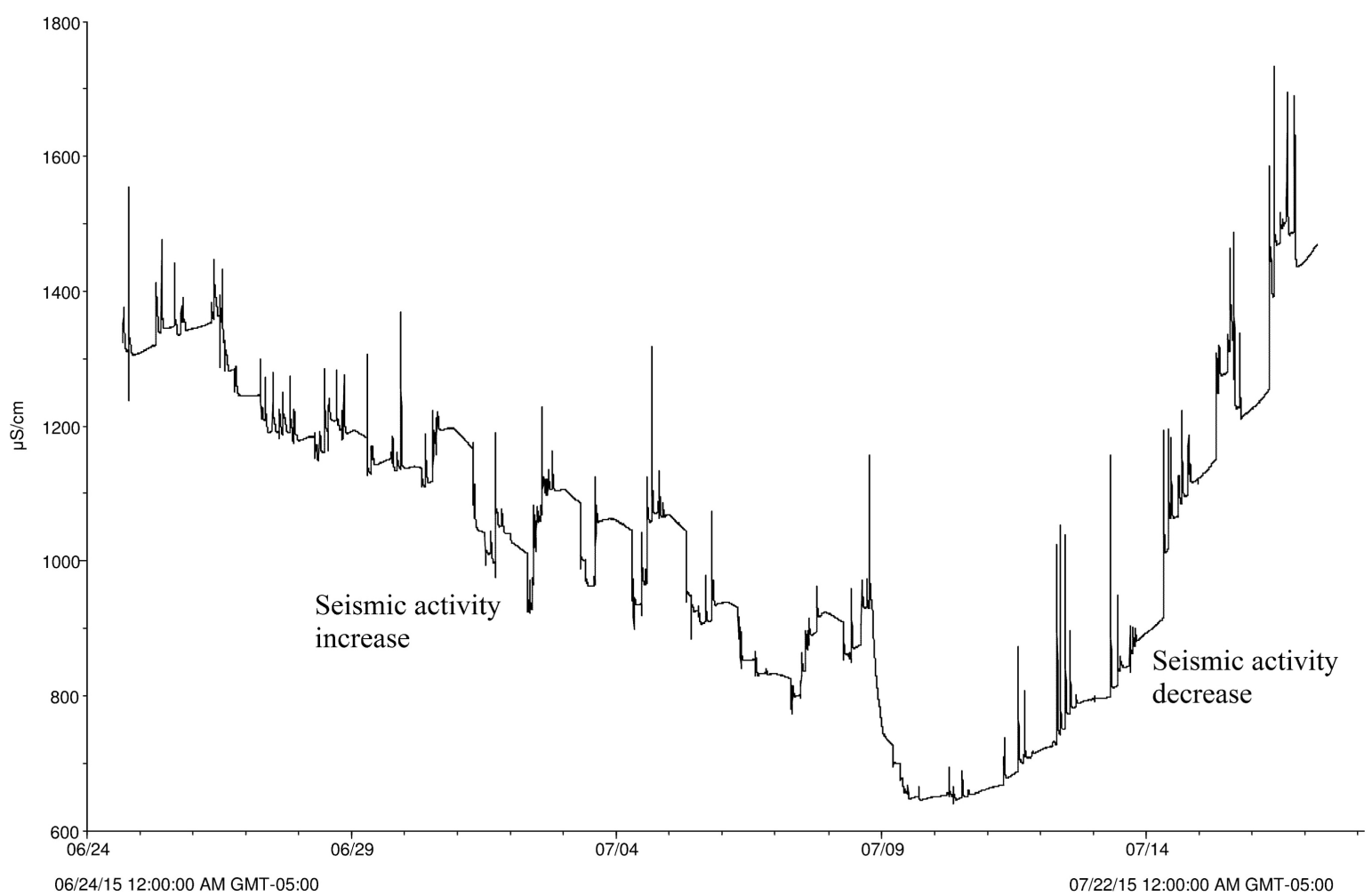

Figure 10. General behavior conductivity observed in the CAW02 site. This monitoring data correspond to a period of June 24 to July 14 of 2015 only.

\section{Site CAW02: 24 hours Conductivity Behavior}

Period: June 24 to July 16, 2015

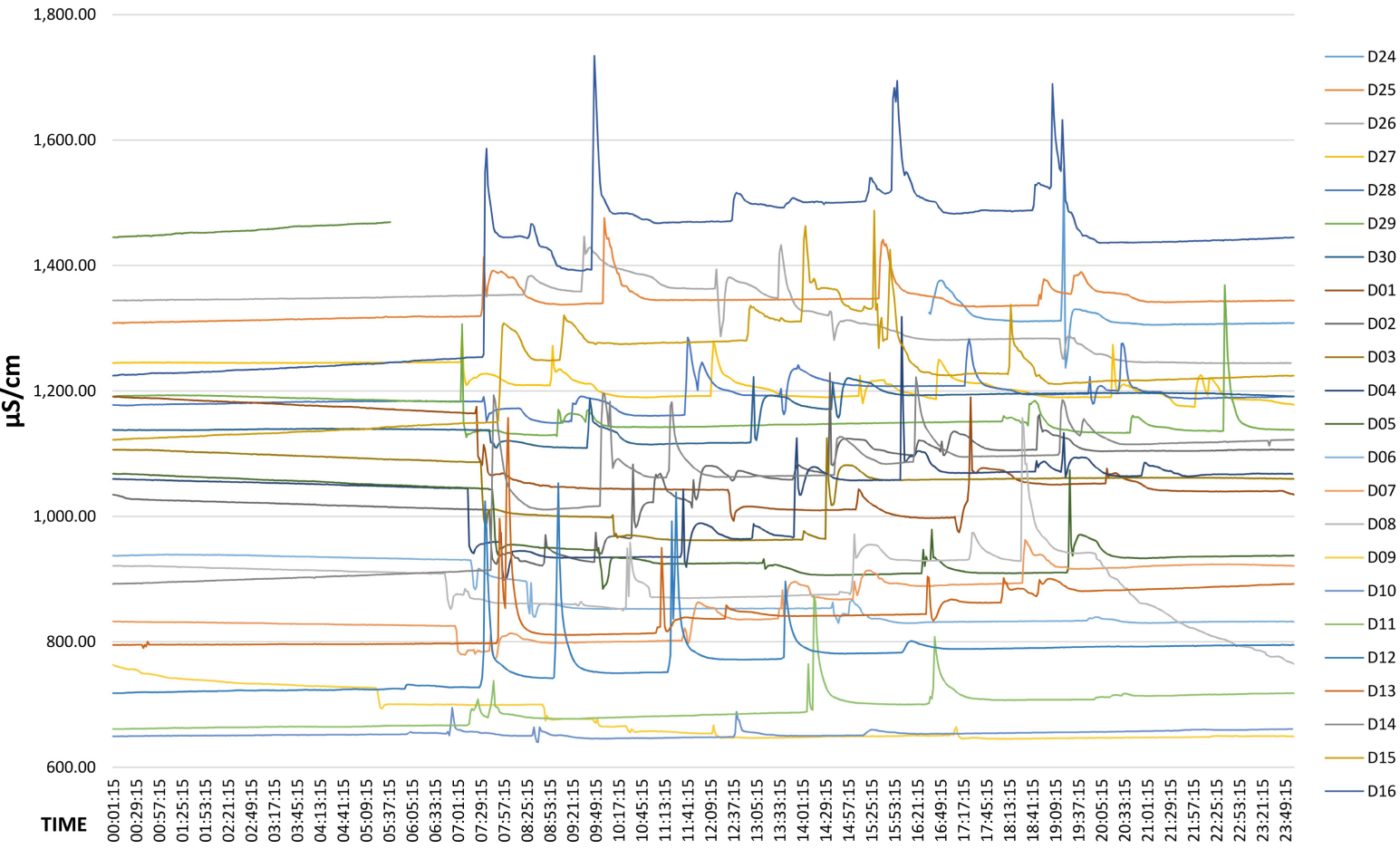

Figure 11. Conductivity behavior in multiple 24-hour data sets during 16 days. 


\section{Conductivity behavior Site CAW01}

Period: Mach 2 to May 11, 2015

1400

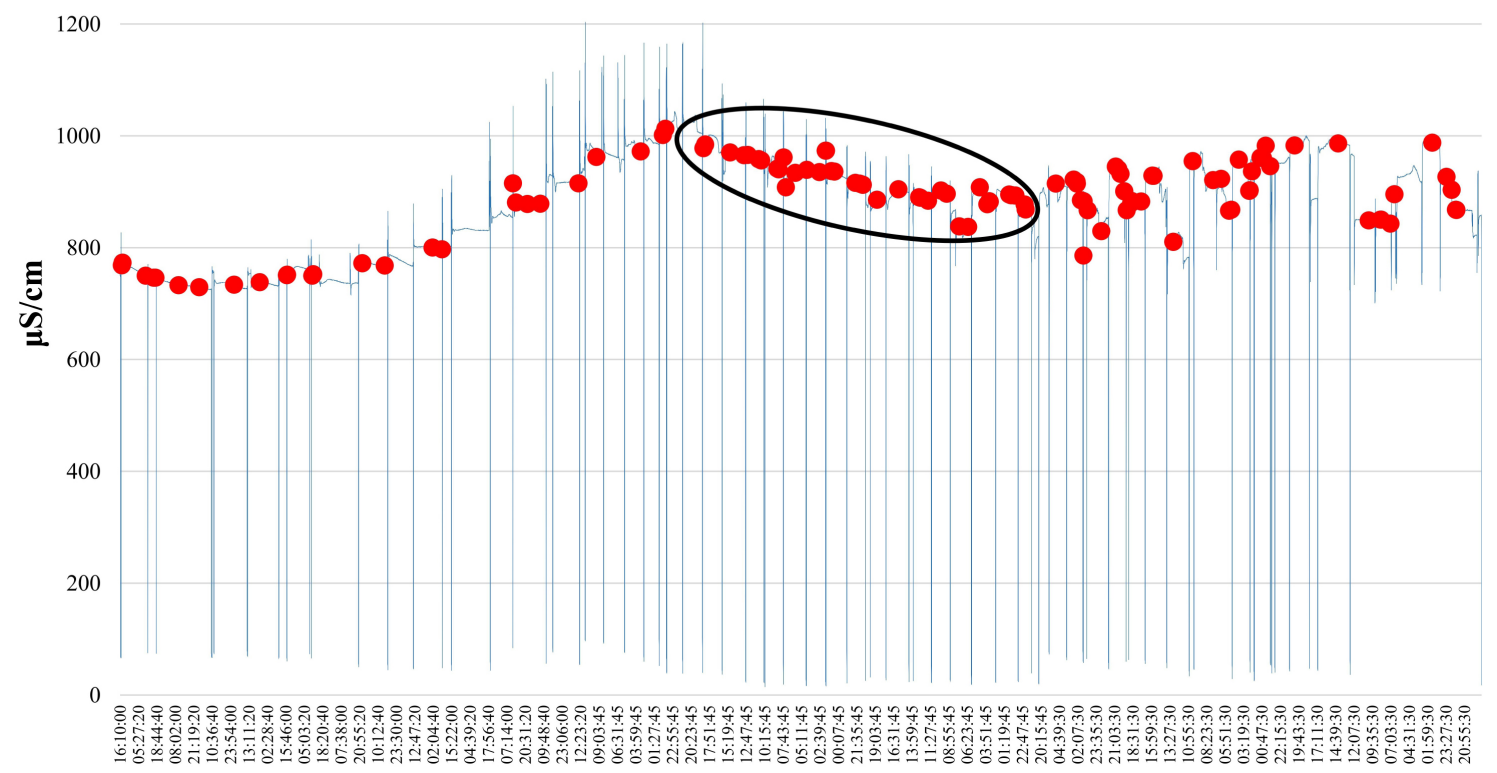

Figure 12. Conductivity behavior from March 2 to May 11 of 2015, corresponding to 61 days of monitoring. During that period 117 seismic events (red dots) were presented, 29 events matched with the data positive trend, and 90 events with the data negative trend, 44 of them (enclosed in the ellipse in black) were presented before the line graph become erratic.

\section{Conductivity behavior Site CAW02 \\ Period: May 11 to July 17, 2015}

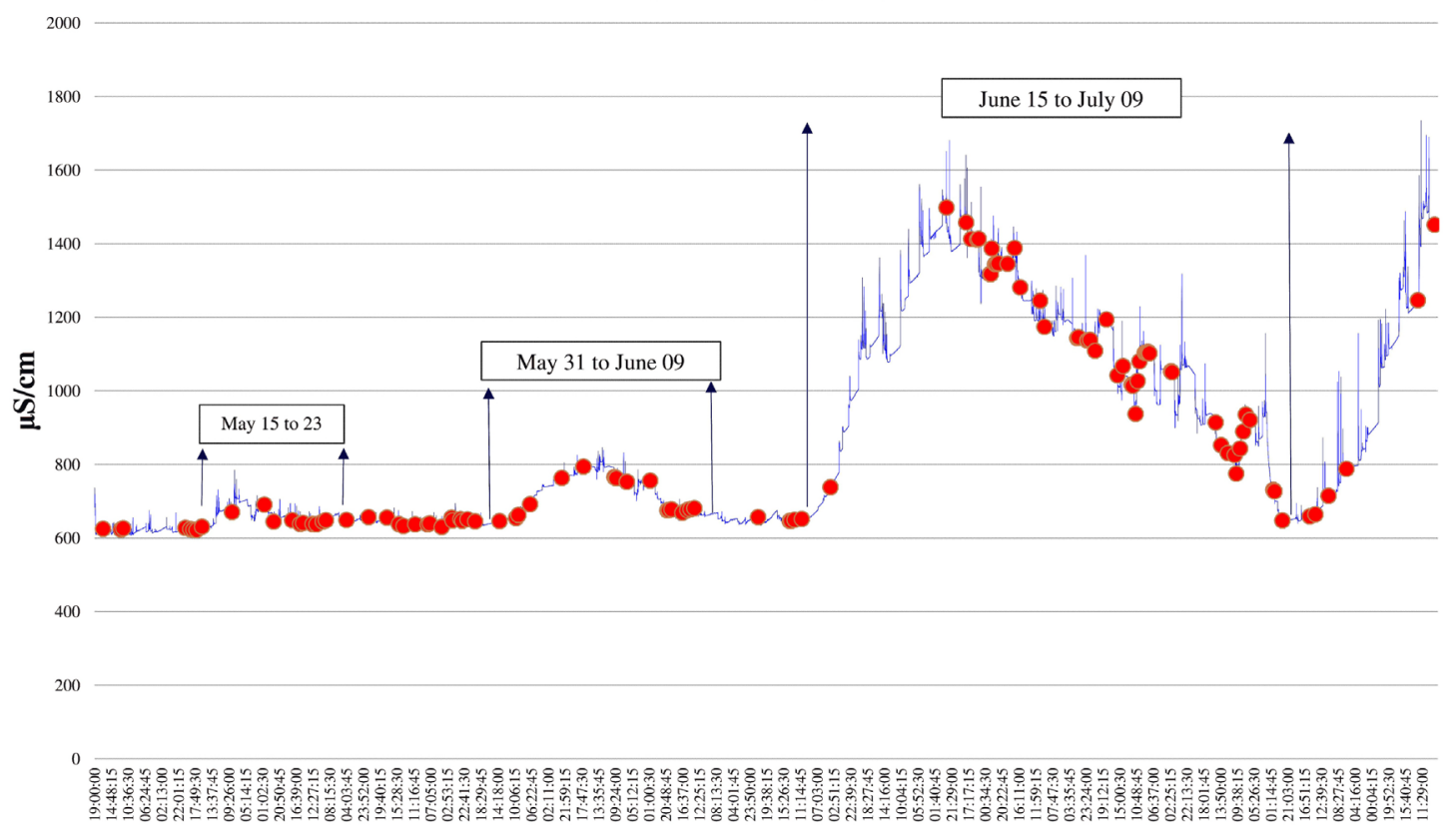

Figure 13. Conductivity behavior from March 11 to July 17 of 2015, corresponding to 61 days of monitoring, 118 seismic event (red dots) were manifested during this period; in the main oscillation 54 seismic events leading up to an earlier period of six days of no presence of seismic activity. 
The conductivity trending of data shows until three diurnal variations, either decrease or increase the conductivity, this behavior may point out that the internal flow of water is extremely fast indicating a vigorous recharge.

- The use of artesian wells by owners to do their household domestic chores could be an important factor that promotes fast changes in conductivity, but not at all, other phenomena could be involved (presence of slight seismic movements; electromagnetic energy fluxes around surroundings; slight tilting of ground by recurrent seismicity).

The conductivity records of artesian wells show fluctuations at several scales of time, from short periods of less than an hour, more than one day or a week and possibly months. The records until now obtain at least two interesting behaviors:

- In shorts series of time there is not clear evidence in the conductivity monitoring results that prove the flux of electromagnetic energy around surroundings. For periods of monitoring time of 24 hours (16 days) after 22:00 hours almost no conductivity occurred, from 7:00 to 22:00 the tendency is positive and very fluctuated and the possibly human factor is the cause of such atypical variations.

- The data analysis for long periods of data series of conductivity (61 days) and seismic events shows that there is a subtle relationship between seismic intensity and large conductivity fluctuation: when the number of seismic events becomes intense, conductivity decreases and vice versa, resulting large fluctuations that grow over time.

Before an earthquake, the behavior of conductivity records shows a possible swing long-term energy like a wave.

\section{Acknowledgements}

The authors appreciatively acknowledge the contributions to this research to M.S. David Nimick, Research Hydrologist (Emeritus), United States Geological Survey (USGS); his invaluable experience and guidance has helped to further understand the phenomena studied and will enhance the scientific design in later studies; in the same way to Engineer José Francisco Hernández Pérez, Head of the Center of Proposed Draft of the South Pacific, regional office of the Coordination of Hydroelectric Projects (CFE), for the logistic support, transportation, human and financial resources provided, without this crucial help would have been extremely difficult for completing this research; as well as to Andrés Suasto A., Oscar E. González A, Ricardo Vázquez H. and José H. Granados Z., for their support and solidarity during the trips.

\section{References}

[1] Athanasiou, M.A., Anagnostopoulos, G.C., Iliopoulos, A.C., Pavlos, G.P. and David, C.N. (2011) Enhanced ULF Radiation Observed by DEMETER Two Months around the strong 2010 Haiti Earthquake. Natural Hazards and Earth System Sciences, 11, 1091-1098. http://dx.doi.org/10.5194/nhess-11-1091-2011

[2] Athanasiou, M.A., Anagnostopoulos, G.C., David, C.N. and Machairides, G.G. (2015) The Ultra Low Frequency Electromagnetic Radiation Observed in the Topside Ionosphere above Boundaries of Tectonic Plates. Journal of Geophysical Research, 4, 31-39. http://dx.doi.org/10.4081/rg.2014.5001

[3] Koshevaya, N.M.S., Grimalsky, V., Urquiza, G., Tecpoyotl, M., Kotsarenko, A. and Yutsis, V. (2012) Explosions and Seismic Phenomena Based on Exciting of Acoustic-Electromagnetic Waves. Natural Science, 4, 652-658. http://dx.doi.org/10.4236/ns.2012.428086

[4] Hayakawa, M., Raulin, J.P., Kasahara, Y., Bertoni, F.C.P., Hobara, Y. and Guevara-Day, W. (2011) Ionospheric Perturbations in Possible Association with the 2010 Haiti Earthquake, as Based on Medium-Distance Subionospheric VLF Propagation Data. Natural Hazards and Earth System Sciences, 11, 513-518. http://dx.doi.org/10.5194/nhess-11-513-2011

[5] Hayakawa, M., Hattori, K. and Ohta, K. (2007) Monitoring of ULF (Ultra-Low-Frequency) Geomagnetic Variations Associated with Earthquakes. Sensors, 7, 1108-1122. http://dx.doi.org/10.3390/s7071108

[6] Koshevaya, S.V., Pérez-Enríquez, R. and Kotsarenko, N.Y. (1997) The Detection of Electromagnetic Processes in the Ionosphere Caused by Seismic Activity. Geofisica Internacional, 36, 55-60.

[7] Araiza-Quijano, G. and Hernandez-del-Valle, M.R. (1996) Some Observations of Atmospheric Luminosity as a Possible Earthquake Precursor. Geofisica Internacional, 35, 403-408.

[8] Campbell, W.H. (2009) Natural Magnetic Disturbance Fields, Not Precursors, Preceding the Loma Prieta Earthquake. Journal of Geophysical Research: Space Physics, 114, Article ID: A05307. http://dx.doi.org/10.1029/2008JA013932 
[9] Cicerone, R.D., Ebel, J.E. and Britton, J. (2009) A Systematic Compilation of Earthquake Precursors. Tectonophysics, 476, 371-396. http://dx.doi.org/10.1016/j.tecto.2009.06.008

[10] Freund, F.T. (2007) Pre-Earthquake Signals_-Part I: Deviatoric Stresses Turn Rocks into a Source of Electric Currents. Natural Hazards and Earth System Sciences, 7, 535-541. http://dx.doi.org/10.5194/nhess-7-535-2007

[11] Freund, F.T., Takeuchi, A. and Lau, B.W.S. (2006) Electric Currents Streaming out of Stressed Igneous Rocks-A Step towards Understanding Pre-Earthquake Low Frequency Em Emissions. Physics and Chemistry of the Earth, Parts A/B/C, 31, 389-396. http://dx.doi.org/10.1016/j.pce.2006.02.027

[12] Freund, F.T. (2003) Rocks That Crackle and Sparkle and Glow : Strange Pre-Earthquake Phenomena. Journal of Scientific Exploration, 17, 37-71.

[13] Shiro, B., Freund, F., Cagle, Y., Pilorz, S. and Hollis-Watts, P. (2012) Measuring Ion Currents and Electric Fields Caused by Earthquakes, Volcanoes, and Lightning in the Mesosphere. NSRC, 27-29 February 2012, Palo Alto, 1-3.

[14] Hasbi, A.M., Ali Mohd, M.A. and Misran, N. (2011) Ionospheric Variations before Some Large Earthquakes over Sumatra. Natural Hazards and Earth System Sciences, 11, 597-611. http://dx.doi.org/10.5194/nhess-11-597-2011

[15] Liperovsky, V.A., Meister, C.V., Mikhailin, V.V., Bogdanov, V.V., Umarkhodgaev, P.M. and Liperovskaya, E.V. (2011) Electric Field and Infrared Radiation in the Troposphere before Earthquakes. Natural Hazards and Earth System Sciences, 11, 3125-3133. http://dx.doi.org/10.5194/nhess-11-3125-2011

[16] Pulinets, S.A., Contreras, A.L. and Ciraolo, L. (2003) Total Electron Content Variations in the Ionosphere before the Colima, Mexico, Earthquake of 21 January 2003. Geofisica Internacional, 44, 369-377.

[17] Dunajecka, M.A. and Pulinets, S.A. (2005) Atmospheric and Thermal Anomalies Observed around the Time of Strong Earthquakes in Mexico. Atmosfera, 18, 235-247.

[18] Koren, I., Altaratz, O., Remer, L.A., Feingold, G., Martins, J.V. and Heiblum, R.H. (2012) Aerosol-Induced Intensification of Rain from the Tropics to the MID-LATITudes. Nature Geoscience, 5, 118-122. http://dx.doi.org/10.1038/ngeo1364

[19] Fidani, C. (2010) The Earthquake Lights (EQL) of the 6 April 2009 Aquila Earthquake, in Central Italy. Natural Hazards and Earth System Sciences, 10, 967-978. http://dx.doi.org/10.5194/nhess-10-967-2010

[20] Heraud, J.A. and Lira, J.A. (2011) Co-seismic Luminescence in Lima, $150 \mathrm{~km}$ from the Epicenter of the Pisco, Peru Earthquake of 15 August 2007. Natural Hazards and Earth System Sciences, 11, 1025-1036. http://dx.doi.org/10.5194/nhess-11-1025-2011

[21] Kawaguchi, Y. (1998) Charged Particle Emission and Luminescence upon Bending Fracture of Granite. Japanese Journal of Applied Physics Part 1: Regular Papers Short Notes \& Review Papers, 37, 3495-3499. http://dx.doi.org/10.1143/JJAP.37.3495

[22] Silva, H.G., Bezzeghoud, M., Reis, A.H., Rosa, R. N., Tlemĉani, M., Araújo, A.A., Serrano, C., Borges, J.F., Caldeira, B. and Biagi, P.F. (2011) Atmospheric Electrical Field Decrease during the $M=4.1$ Sousel Earthquake (Portugal). Natural Hazards and Earth System Sciences, 11, 987-991. http://dx.doi.org/10.5194/nhess-11-987-2011

[23] Asada, T., Baba, H., Kawazoe, M. and Sugiura, M. (2001) An Attempt to Delineate Very Low Frequency Electromagnetic Signals Associated with Earthquakes. Earth, Planets and Space, 53, 55-62. http://dx.doi.org/10.1186/BF03352362

[24] Bleier, T., Dunson, C., Alvarez, C., Freund, F. and Dahlgren, R. (2010) Correlation of Pre-Earthquake Electromagnetic Signals with Laboratory and Field Rock Experiments. Natural Hazards and Earth System Sciences, 10, 1965-1975. http://dx.doi.org/10.5194/nhess-10-1965-2010

[25] Guo, G. and Wang, B. (2008) Cloud Anomaly before Iran Earthquake. International Journal of Remote Sensing, 29, 1921-1928. http://dx.doi.org/10.1080/01431160701373762

[26] Guo, G. and Jie, Y. (2013) Three Attempts of Earthquake prediction with satellite cloud images. Natural Hazards and Earth System Sciences, 13, 91-95. http://dx.doi.org/10.5194/nhess-13-91-2013

[27] Li, L.-X., Wu. J.-P. and Liu, S.-J. (2009) Space Observed Two Abnormal Linear Clouds before Wenchuan Earthquake. 3rd IASME/WSEAS International Conference on Geology and Seismology, Cambridge, 24-26 February 2009, 138-143.

[28] Shou, Z. (2007) The Cloud of the M8.4 Indonesian Earthquake on September 12, 2007. New Concepts in Global Tectonics Newsletter, 45, 31-33.

[29] Buskirk, R.E., Frohlich, C. and Latham, G.V. (1981) Unusual Animal Behavior before Earthquakes: A Review of Possible Sensory Mechanisms. Reviews of Geophysics, 19, 247-270. http://dx.doi.org/10.1029/RG019i002p00247

[30] Frohlich, C. and Buskirk, R.E. (1980) Can Fish Detect Seismic Waves? Geophysical Research Letters, 7, 569-572. http://dx.doi.org/10.1029/GL007i008p00569

[31] Grant, R.A., Halliday, T., Balderer, W.P., Leuenberger, F., Newcomer, M., Cyr, G. and Freund, F.T. (2011) Ground 
Water Chemistry Changes before Major Earthquakes and Possible Effects on Animals. International Journal of Environmental Research and Public Health, 8, 1936-1956. http://dx.doi.org/10.3390/ijerph8061936

[32] Grant, R. and Halliday, T. (2010) Predicting the Unpredictable, Evidence of Pre-Seismic Anticipatory Behaviour in the Common Toad. Journal of Zoology, 281, 263-271. http://dx.doi.org/10.1111/j.1469-7998.2010.00700.x

[33] Hallett, M. (1992) Percetion of the Pre-Seismic Signals among Reptiles. The Case of the Parma Apennines (Italy). New Concepts In Global Tectonics Newsletter, 15, 1106-1107.

[34] Kirschvink, J.L. (2000) Earthquake Prediction by Animals: Evolution and Sensory Perception. Bulletin of the Seismological Society of America, 90, 312-323. http://dx.doi.org/10.1785/0119980114

[35] Lighton, J.R.B. and Duncan, F.D. (2005) Shaken, Not Stirred: A Serendipitous Study of Ants and Earthquakes. The Journal of Experimental Biology, 208, 3103-3107. http://dx.doi.org/10.1242/jeb.01735

[36] Wang, G., Zhang, Z., Wang, M., Cravotta, C. and Liu, C. (2005) Implications of Ground Water Chemistry and Flow Patterns for Earthquake Studies. Ground Water, 43, 478-484. http://dx.doi.org/10.1111/j.1745-6584.2005.0037.x

[37] Martínez-garcía, F., Colín-cruz, A., Adame-martínez, S. and Ramírez-garcía, J.J. (2015) Atypical Variations of Water Conductivity Prior to Tectonic Earthquakes. International Journal of Geosciences, 6, 1367-1385. http://dx.doi.org/10.4236/ijg.2015.612108

[38] Straser, V. (2009) Luminous Phenomena in the Atmosphere: Signs of Uplift of the Earth’s Crust? The "lights” in Taro Valley (Italy) and Hessdalen (Norway). New Concepts in Global Tectonics Newsletter, 47-56.

[39] Henshaw, D.L., Ward, J.P. and Matthews, J.C. (2008) Can disturbances in the Atmospheric Electric Field Created by Powerline Corona Ions Disrupt Melatonin Production in the Pineal Gland? Journal of Pineal Research, 45, 341-350. http://dx.doi.org/10.1111/j.1600-079X.2008.00594.x

[40] Henshaw, D.L. (2004) Childhood Leukaemia and EMFs? Mobile Phones and Brain Tumours, Risks and Causal Pathways Two Types of Fields from the Electricity Supply: Electric Fields (EFs) \& Magnetic Fields (MFs) Doubling of Childhood Leukaemia Risk Increased Incidence of Chi. in The 7th Princess Chulabhorn International Science Congress, Bangkok, 3-29 December 2012, 1-17.

[41] Yamamoto, J., González-Moran, T., Quintanar, L., Zavaleta, A.B., Zamora, A. and Espindola, V.H. (2013) Seismic Patterns of the Guerrero-Oaxaca, Mexico Region, and Its Relationship to the Continental Margin Structure. Geophysical Journal International, 192, 375-389. http://dx.doi.org/10.1093/gji/ggs025

[42] Pérez-Campos, X., Kim, Y.H., Husker, A., Davis, P.M., Clayton, R.W., Iglesias, A., Pacheco, J.F., Singh, S.K., Manea, V.C. and Gurnis, M. (2008) Horizontal Subduction and Truncation of the Cocos Plate Beneath Central Mexico. Geophysical Research Letters, 35, 1-6. http://dx.doi.org/10.1029/2008GL035127

[43] Foppiano, A.J., Ovalle, E.M., Bataille, K. and Stepanova, M. (2008) Ionospheric Evidence of the May 1960 Earthquake over Concepción? Geofisica Internacional, 47, 179-183.

[44] Liperovsky, V.A. and Meister, M. (1990) Electromagnetic Disturbances Associated With Earthquakes: An Analysis of Ground-Based and Satellite Data. Journal of Scientific Exploration, 4, 203-211.

[45] Walker, S.N., Kadirkamanathan, V. and Pokhotelov, O.A. (2013) Changes in the Ultra-Low Frequency Wave Field during the Precursor Phase to the Sichuan Earthquake: DEMETER Observations. Annals of Geophysics, 31, 15971603. http://dx.doi.org/10.5194/angeo-31-1597-2013

[46] Akinaga, Y., Hayakawa, M., Liu, J.Y., Yumoto, K. and Hattori, K. (2001) A Precursory ULF Signature for the Chi-Chi Earthquake in Taiwan. Natural Hazards and Earth System Sciences, 1, 33-36. http://dx.doi.org/10.5194/nhess-1-33-2001

[47] Zhang, X., Shen, X., Parrot, M., Zeren, Z., Ouyang, X., Liu, J., Qian, J., Zhao, S. and Miao, Y. (2012) Phenomena of Electrostatic Perturbations before Strong Earthquakes (2005-2010) Observed on DEMETER. Natural Hazards and Earth System Sciences, 12, 75-83. http://dx.doi.org/10.5194/nhess-12-75-2012

[48] Saraf, A. K. and Choudhury, S. (2005) Thermal Remote Sensing Technique in the Study of Pre-Earthquake Thermal Anomalies. Journal of Indian Geophysical Union, 9, 197-207.

[49] Saraf, A. K., Choudhury, S., Rawat, V. and Banerjee, P. (2008) Detecting Earthquake Precursor: A Thermal Remote Sensing Approach. 1-13.

[50] Sharma, D. K., Rai, J., Chand, R. and Israil, M. (2006) Effect of Seismic Activities on Ion Temperature in the F2 Region of the Ionosphere. Atmosfera, 19, 1-7.

[51] Bleier, T., Dunson, C., Maniscalco, M., Bryant, N., Bambery, R. and Freund, F. (2009) Investigation of ULF Magnetic Pulsations, Air Conductivity Changes, and Infra Red Signatures Associated with the 30 October Alum Rock M5.4 Earthquake. Natural Hazards and Earth System Sciences, 9, 585-603. http://dx.doi.org/10.5194/nhess-9-585-2009

[52] Saradjian, M. R. and Akhoondzadeh, M. (2011) Thermal Anomalies Detection before Strong Earthquakes $(M>6.0)$ Using Interquartile, Wavelet and Kalman Filter Methods. Natural Hazards and Earth System Sciences, 11, 1099-1108. http://dx.doi.org/10.5194/nhess-11-1099-2011 
[53] Chapin, T.P., Todd, A.S. and Zeigler, M.P. (2014) Robust, Low-Cost Data Loggers for Stream Temperature, Flow Intermittency, and Relative Conductivity Monitoring. Water Resources Research, 50, 5216-5234. http://dx.doi.org/10.1002/2013WR015158

[54] Nimick, D.A., Gammons, C.H. and Parker, S.R. (2011) Diel Biogeochemical Processes and Their Effect on the Aqueous Chemistry of Streams: A Review. Chemical Geology, 283, 3-17. http://dx.doi.org/10.1016/j.chemgeo.2010.08.017

[55] Kostoglodov, V., Singh, S.K., Santiago, J.A. and Franco, S.I. (2003) A Large Silent Earthquake in the Guerrero Seismic Gap, Mexico. Geophysical Research Letters, 30, 1807. http://dx.doi.org/10.1029/2003GL017219

[56] Liu, Y. and Rice, J.R. (2009) Slow Slip Predictions Based on Granite and Gabbro Friction Data Compared to GPS Measurements in Northern Cascadia. Journal of Geophysical Research, 114, 1-19. http://dx.doi.org/10.1029/2008JB006142

[57] Obara, K. and Sekine, S. (2009) Characteristic Activity and Migration of Episodic Tremor and Slow-Slip Events in Central Japan. Earth, Planets and Space, 61, 853-862. http://dx.doi.org/10.1186/BF03353196

[58] Stanica, D. and Stanica, D.A. (2011) Anomalous Pre-Seismic Behavior of the Electromagnetic Normalized Functions Related to the Intermediate Depth Earthquakes Occurred in Vrancea Zone, Romania. Natural Hazards and Earth System Sciences, 11, 3151-3156. http://dx.doi.org/10.5194/nhess-11-3151-2011

\section{Submit or recommend next manuscript to OALib Journal and we will provide best service for you:}

- Publication frequency: Monthly

- 9 subject areas of science, technology and medicine

- Fair and rigorous peer-review system

- Fast publication process

- Article promotion in various social networking sites (LinkedIn, Facebook, Twitter, etc.)

- Maximum dissemination of your research work

Submit Your Paper Online: $\underline{\text { Click Here to Submit }}$

Contact Us: service@oalib.com 